Document downloaded from:

http://hdl.handle.net/10251/153684

This paper must be cited as:

Afonso, CRM.; Vidilli, AL.; Spinelli, JE.; Riva, R.; Amigó, V.; Kiminami, CS. (2017). An assessment of microstructure and properties of laser clad coatings of ultrafine eutectic beta Ti-Fe-Nb-Sn composite for implants. Surface and Coatings Technology. 328:161-171. https://doi.org/10.1016/j.surfcoat.2017.08.035

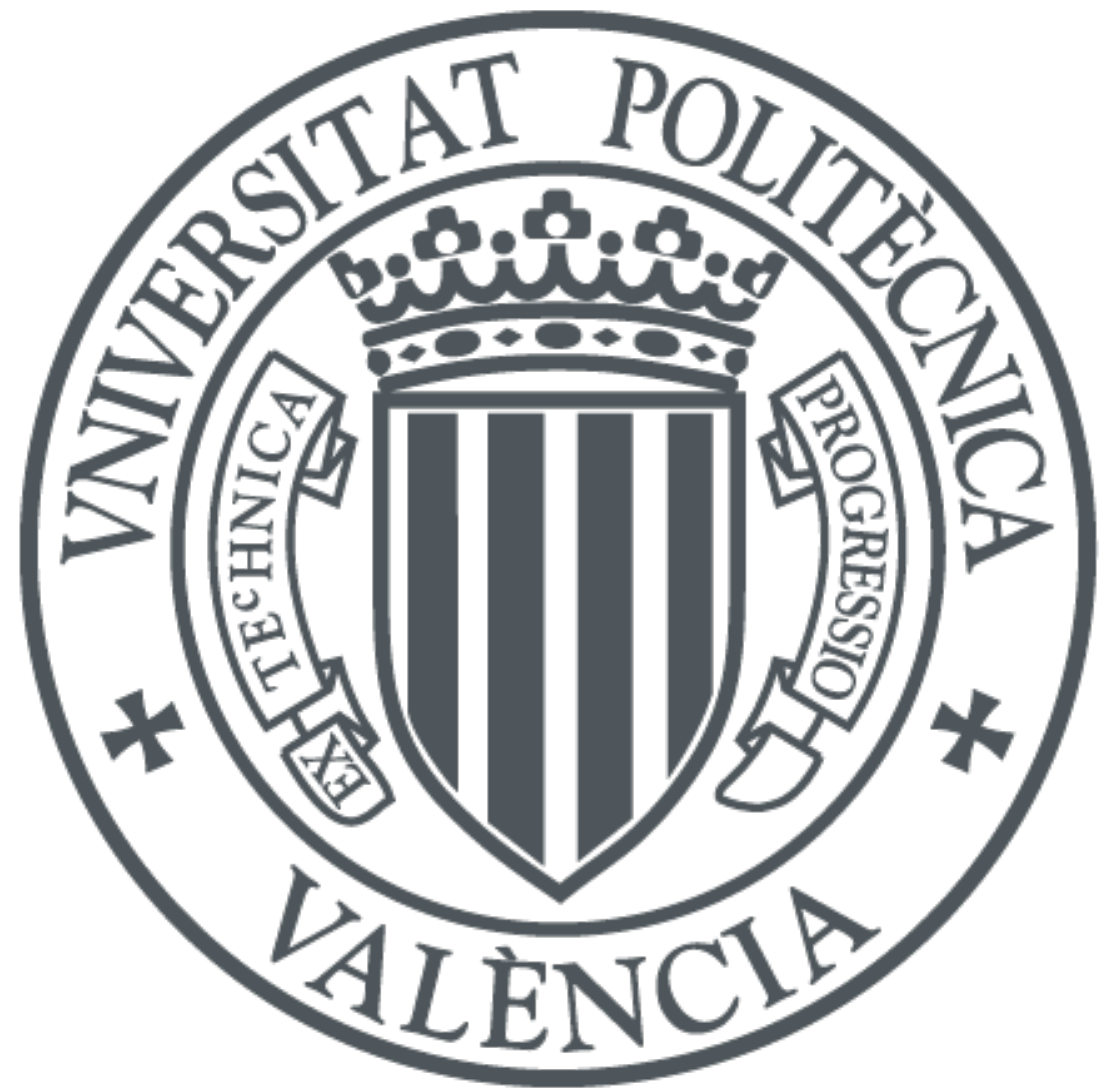

The final publication is available at

https://doi.org/10.1016/j.surfcoat.2017.08.035

Copyright Elsevier

Additional Information 


\title{
An assessment of microstructure and properties of laser clad coatings of ultrafine eutectic $\beta$ Ti-Fe-Nb-Sn composite for implants
}

\author{
C.R.M. Afonso ${ }^{1}$, A. L. Vidilli ${ }^{1}$, J. E. Spinelli ${ }^{1, *}$, R. Riva ${ }^{2}$, \\ V. Amigó ${ }^{3}$ and C. S. Kiminami ${ }^{1}$ \\ ${ }^{1}$ Department of Materials Engineering (DEMa), Federal University of São Carlos (UFSCar), CEP 13565-905 São Carlos, \\ SP, Brazil. \\ ${ }^{2}$ Institute for Advanced Studies (IEAv), Department of Aerospace Science and Technology (DCTA), PO Box 6044, 12228- \\ 970, São José dos Campos, SP, Brazil. \\ ${ }^{3}$ Institute of Materials Technology (ITM), Universitat Politècnica de València (UPV), P.O.Box 22012, E-46071, Valencia, \\ Spain.
}

\begin{abstract}
Ultrafine eutectic Ti-based nanocomposite alloys exhibit high mechanical strength (1,800-2,500 MPa), elastic modulus nearest human bone (50-110 GPa) and good corrosion resistance due to a combination of soft $\beta$ - Ti (bcc) matrix and hard/refined TiFe and/or $\mathrm{Ti}_{3} \mathrm{Sn}$ intermetallic particles. The present study focuses on the production and characterization of Ti-Fe-Nb-Sn eutectic alloys using biocompatible $\beta$ stabilizer elements, such as $\mathrm{Nb}, \mathrm{Fe}$ and $\mathrm{Sn}$. Different fabrication techniques based on rapid solidification and with further evaluation of the generated properties may be highlighted considering the application of these alloys as implant material. In the present investigation, the proposed processing routes comprise single tracks and coatings (overlapped tracks) by laser melting of prealloyed powders of the $\mathrm{Ti}_{66} \mathrm{Fe}_{20} \mathrm{Nb}_{8} \mathrm{Sn}_{6}$ alloy deposited into a Ti substrate. To select this composition, three Ti-Fe-Nb based compositions of interest were originally generated under bulk conditions by using a suction casting apparatus and were further evaluated. All samples were analyzed by metallography, X-ray diffraction (XRD), scanning electron microscopy (SEM-EBSD and SEM-EDS), microhardness, nanohardness and elastic modulus. The results showed that the proportions of the formed $\mathrm{TiFe}$ and $\mathrm{Ti}_{3} \mathrm{Sn}$ intermetallic particles dispersed within the soft $\beta$-Ti matrix play a fundamental role on the final properties. Lower elastic modulus $(\mathrm{E} \sim 72 \mathrm{GPa})$ is associated with the $\mathrm{Ti}_{66} \mathrm{Fe}_{20} \mathrm{Nb}_{8} \mathrm{Sn}_{6}$ bulk alloy, whereas laser clad coatings for the $\mathrm{Ti}_{66} \mathrm{Fe}_{20} \mathrm{Nb}_{8} \mathrm{Sn}_{6}$ alloy showed a broad range of nanohardness (4.8 - 8.0 GPa) and elastic modulus (98 - $150 \mathrm{GPa})$ depending on the related laser power and scanning speeds.
\end{abstract}

Keywords: Ti-Fe base alloy, rapid solidification, laser cladding, ultrafine eutectic, implant coatings.

* Corresponding author $\rightarrow$ E-mail address: spinelli@ufscar.br 


\section{Introduction}

A synthesis of new Ti-based ultrafine composites and bulk metallic glasses (BMG) alloys was carried out due to their good engineering properties. These alloys are industrially important as structural and functional materials [1-5]. Ti-based BMG alloys exhibit high strength (1800-2500 MPa), low elastic modulus (50-110 GPa) and, as expected, good corrosion resistance in various solutions. For instance, $\mathrm{Ti}_{45} \mathrm{Zr}_{10} \mathrm{Pd}_{10} \mathrm{Cu}_{31} \mathrm{Sn}_{4} \mathrm{BMG}$ exhibits a good combination of high mechanical properties, corrosion resistance (chemical biocompatibility) and is considered suitable for the production of alloys with high glass forming ability (GFA).

High strength Ti-based nanostructured/ultrafine eutectic composites present high fracture strength ( 2000-2600 MPa) and larger plasticity (>4\%) compared with BMGs. One example is the Ti-Cu-Ni-Sn-Nb alloy composed of micrometric $\beta$-Ti dendrites in a nanostructure matrix, which exhibits a high strength of $2400 \mathrm{MPa}$ and a plastic strain to fracture of $\sim 15 \%$ [2]. Usually mechanical properties of alloys can be improved by microstructure refinement, as shown for hypoeutectic, eutectic or hypereutectic Ti-Fe-based alloys, consisting of primary phases and $\mathrm{TiFe}+\beta$-Ti eutectic constituents exhibiting better mechanical properties (strength $\sim 2200 \mathrm{MPa}$, plasticity 7\%) and modified with elements such as $\mathrm{Sn}, \mathrm{Co}$ and $\mathrm{Nb}[4-7]$.

The strength of conventional crystalline alloys follows the Hall-Petch relation, which predicts an increase in the strength when the grain sizes are decreased. Ti-based alloys with low density, high strength and ductility, as well as high chemical stability are of particular interest to energy efficient constructions. The ductility of nanostructured materials can be improved by embedding a submicron soft phase into a quasicrystal or nano-sized second phase [4-8]. Researchers have reported on the formation of complex phases and hardening mechanisms for supersaturated $\beta$-Ti solid solutions including phase separation [9-12] and 
ultrafine structure composed by $\beta$-Ti/TiFe eutectic in Ti-based ultrafine composite alloys [11$15]$.

Metallic alloys used as biomaterials have much higher elastic modulus $(E)$ than the one from human bone ( $E=10$ to $30 \mathrm{GPa})$ : Stainless Steel (200 GPa), Co-Cr Alloys (220 GPa), Ti-6Al-4V (110 GPa) and the search for alloys with enhanced mechanical and chemical biocompatibility are required [16]. Some metallic Ti-based systems exhibited an unbalanced combination of elastic modulus and strength, for instance the $\mathrm{Ti}-\mathrm{Nb}-\mathrm{Zr}-\mathrm{Ta}$ system, which shows rather low elastic modulus (i.e., good biomechanical compatibility with bone), but moderate hardness. On the contrary, the Ti-Fe-Sn system shows high yield strength, but also exceedingly high elastic modulus, which could eventually lead to stress shielding effects [17]. In the case of Ti-Fe-Sn, the deformation behavior of ultrafine composites is not fully understood due to the number of possibilities concerning the microstructure formation, which can be very complex. For instance, the alternation of microstructure features due to the variation in solute content may be very significant [17-19]. Moreover, Das and co-authors [6] affirm that Ti-Fe-Sn ultrafine eutectic composite is effective to change the growth of the eutectic phases and destabilize their morphology. Selecting the primary dendrite phase is a key factor to enhancing mechanical behavior. The effects of the cooling rate during rapid solidification on the obtained microstructure configuration of the Ti-Fe-Sn base alloys, however, remain undetermined.

Recently, Han et al. [20] investigated the ultrafine eutectic $\left(\mathrm{Ti}_{65} \mathrm{Fe}_{35}\right)_{100-\mathrm{x}} \mathrm{Sn}_{\mathrm{x}}$ alloys with $\mathrm{x}=0,1$ and 3 at $\%$. The presence of Sn was reported as essential to control not only the dendritic array, but also to decrease the length-scale of the eutectic spacing. Nano-eutectic composites formed as part of the microstructure of Fe-Sn-Ti [21] were reported as having two distinct eutectic structures. The literature reveals a lack of understanding concerning fast cooling processes of Ti-Fe-Sn based alloys, including growth and competition between dendrites and eutectic microstructures. Research in this field would be very helpful to modulate the mechanical properties of these eutectic composites. 
Up to now, research on the $\mathrm{Sn}$ and $\mathrm{Nb}$ combined modified microstructure and mechanical properties for eutectic Ti-Fe base alloys are still restricted. Therefore, the aim of this study is to investigate the microstructure features of the Ti-Fe-Nb-Sn alloys under different processing routes, i.e., $i$. fabrication of bulk plates by suction casting in copper mold and $i$. laser melting of a pre-deposit powder alloy on a Ti substrate. Emphasis is given to studying the correlations between the microstructures and cooling rates, which are calculated for the different conditions adopted during both processing routes. The influences of microstructures and dilutions of elements (in the case of lasers) on hardness and on elastic modulus are also investigated.

\section{Experimental procedure}

Arc-melter equipment was used to prepare around $50 \mathrm{~g}$ of the $\mathrm{Ti}_{63} \mathrm{Fe}_{23} \mathrm{Nb}_{8} \mathrm{Sn}_{6}$, $\mathrm{Ti}_{60} \mathrm{Fe}_{23} \mathrm{Nb}_{8} \mathrm{Sn}_{9}$ and $\mathrm{Ti}_{66} \mathrm{Fe}_{20} \mathrm{Nb}_{8} \mathrm{Sn}_{6}$ (at\%) alloys by using high-purity constituent elements, i.e., $\mathrm{Ti}(99.9 \%), \mathrm{Nb}(99.8 \%)$, electrolytic Fe $(99.7 \%)$ and $\mathrm{Sn}(99.99 \%)$ in a Ti-gettered highpurity argon atmosphere. Samples of each alloy of $15 \mathrm{~g}$ were cut from the ingots and further processed in a Discovery ${ }^{\circledR}$ suction casting system equipped with a copper mold. The copper mold designed in a plate shape, with varied thicknesses, had dimensions of $20 \times 50 \mathrm{~mm}^{2}$. Plates that are $0.5,1.0$, and $2.0 \mathrm{~mm}$ thick were obtained. Details concerning the used casting assembly may be found in Fig. 1(a) by observing the so-called processing route (a). 
Route of processing

(a)

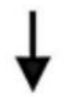

Ti-Fe-Nb-Sn alloy

Copper mold inserted in a suction casting (SC) system

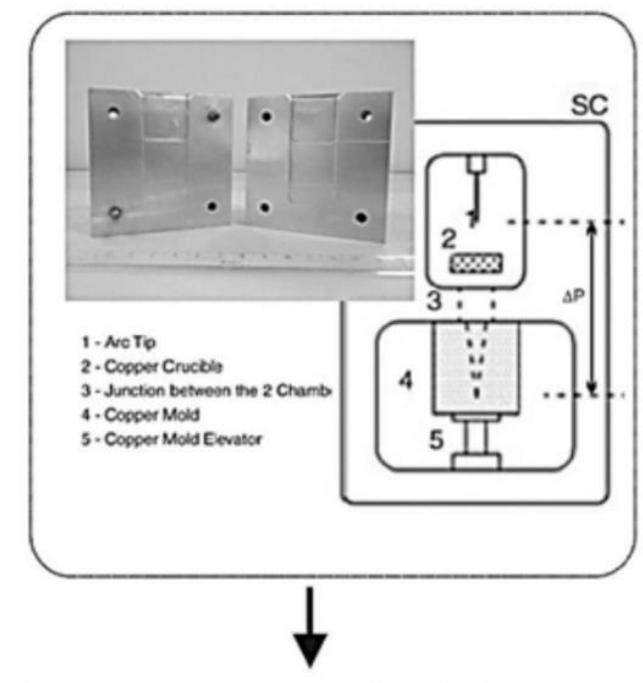

1. Advanced characterization through SEM and XRD

2. Vickers hardness and elastic modulus
Route of processing

(b)

Ti-Fe-Nb-Sn alloy

Laser rapidly solidified samples by

Yb-fiber source

b1 - single tracks

b2-overlapped tracks



Fig. 1. Sequence of processing steps carried out in the Ti-Fe-Nb-Sn alloys: (a) rapid solidification by copper mold in suction casting apparatus followed by a comprehensive microstructural characterization; (b) powder preparation to permit laser melting to be performed following two conditions, which are: single tracks and overlapped tracks (resultant coatings).

The other processing route, as illustrated in Fig. 1(b) includes, firstly, an elemental mixture of the selected $\mathrm{Ti}_{66} \mathrm{Fe}_{20} \mathrm{Nb}_{8} \mathrm{Sn}_{6}$ alloy powders with a mass of around $100 \mathrm{~g}$. These compositions were obtained by an elemental combination of pure Ti powder $(99.5 \% / \sim 100 \mu \mathrm{m}$ in size), pure $\mathrm{Nb}$ powder (99.8\%/ 50 $\mu \mathrm{m}$ in size), gas atomized $\mathrm{Fe}-20 \mathrm{Nb}$ (wt.\%) master alloy $(<180 \mu \mathrm{m}$ in size) and impulse atomized $\mathrm{Sn}-0.7 \mathrm{Cu}($ wt.\%) powder alloy (size range of 106$180 \mu \mathrm{m})$. Secondly, a high-energy ball milling (HEBM) processing step for the production of pre-alloyed and homogenized powders was performed by using a planetary mill for $2 \mathrm{~h}$.

Finally, a substrate of c.p. Ti of $2 \mathrm{~mm}$ of thickness containing a pre-placed $500 \mu \mathrm{m}$ thick layer 
of the ball milled powder of the $\mathrm{Ti}_{66} \mathrm{Fe}_{20} \mathrm{Nb}_{8} \mathrm{Sn}_{6}$ alloy onto its surface was melted by laser cladding. For this purpose, a Yb- fiber laser (IPG, YLS2000) with an emitted radiation wavelength of $\lambda=1070 \mathrm{~nm}$ and maximum power of $2000 \mathrm{~W}$ was used. The laser beam was transmitted via an optical fiber of $100 \mu \mathrm{m}$ of diameter to a $160 \mathrm{~mm}$ focal length lens. In this configuration, the laser beam diameter in the focus position was $100 \mu \mathrm{m}$. The samples were attached to a CNC XY table. In this study, the whole set of experiments was conducted with the sample surface positioned $8 \mathrm{~mm}$ below the focus lens. The laser beam in this out-of-focus position presented a quasi-Gaussian profile with a diameter of $1 \mathrm{~mm} \mathrm{[22].}$

The laser melting experiments were carried out using single tracks and overlapped tracks (coatings) using different laser beam power, scanning speed and beam overlapping distance. A summary including the examined alloys, techniques and laser parameters adopted in the present investigation can be seen in Table 1.

Table 1. Studied alloys and main parameters used during laser cladding of the Ti-Fe-Nb-Sn alloys.

\begin{tabular}{|c|c|c|c|c|c|c|}
\hline \multirow[b]{2}{*}{$\begin{array}{l}\text { Suction } \\
\text { casting }\end{array}$} & \multicolumn{3}{|c|}{ Single track laser * } & \multicolumn{3}{|c|}{ Overlapped tracks laser $* *$} \\
\hline & Alloy & $\begin{array}{c}\text { Scanning } \\
\text { speed } \\
(\mathrm{mm} / \mathrm{s})\end{array}$ & $\begin{array}{c}\text { Power } \\
\text { (W) }\end{array}$ & Alloy & $\begin{array}{l}\text { Power } \\
\text { (W) }\end{array}$ & $\begin{array}{c}\text { Scanning } \\
\text { speed } \\
(\mathrm{mm} / \mathrm{s})\end{array}$ \\
\hline \multirow{3}{*}{$\mathrm{Ti}_{66} \mathrm{Fe}_{20} \mathrm{Nb}_{8} \mathrm{Sn}_{6}$} & \multirow{5}{*}{$\mathrm{Ti}_{66} F \mathrm{Fe}_{20} \mathrm{Nb}_{8} \mathrm{Sn}_{6}$} & \multirow{5}{*}{$\begin{array}{c}16.7 \\
33.3, \\
66.7 \\
100 \\
150\end{array}$} & \multirow{5}{*}{$\begin{array}{l}200, \\
400, \\
600, \\
800\end{array}$} & \multirow{5}{*}{$\mathrm{Ti}_{66} \mathrm{Fe}_{20} \mathrm{Nb} \mathrm{b}_{8} \mathrm{Sn}_{6}$} & $\begin{array}{c}\text { LC-1: } \\
800\end{array}$ & 33.3 \\
\hline & & & & & $\begin{array}{c}\text { LC-2: } \\
600\end{array}$ & 33.3 \\
\hline & & & & & $\begin{array}{c}\text { LC-3: } \\
600\end{array}$ & 16.7 \\
\hline $\mathrm{Ti}_{60} \mathrm{Fe}_{23} \mathrm{Nb}_{8} \mathrm{Sn} 9$ & & & & & $\begin{array}{c}\text { LC-4: } \\
400\end{array}$ & 16.7 \\
\hline $\mathrm{Ti}_{63} \mathrm{Fe}_{23} \mathrm{Nb}_{8} \mathrm{Sn}_{6}$ & & & & & $\begin{array}{c}\text { LC-5: } \\
200\end{array}$ & 16.7 \\
\hline
\end{tabular}

* Single tracks were performed for each combination of power, $\mathrm{P}(\mathrm{W})$ and scanning speed, $\mathrm{Vb}(\mathrm{mm} / \mathrm{s})$.

** 50\% (single track width) of superposition of tracks.

Bulk alloys, laser processed single tracks and coatings (overlapped tracks) specimens of the Ti-Fe-Nb-Sn alloys were submitted to microstructure characterization using X-ray diffraction (XRD), scanning electron microscopy (SEM) coupled to energy dispersive 
spectroscopy (EDS), as well as EBSD analysis, which was used to characterize the laser processed coatings, their microstructures and formed crystalline phases. XRD measurements were performed on a Siemens diffractometer, model D5005 using $\mathrm{Cu}-\mathrm{K}_{\alpha}$ radiation $(\lambda=$ $1.5418 \AA$ ) and $1 \%$ min scanning from 20 to $90^{\circ}$ degrees (20). A Field Emission Gun (FEG) Scanning Electron Microscope (SEM) Philips (XL30 FEG) coupled to an Energy Dispersive Spectroscope - EDS (Oxford Link ISIS 300) was used. Furthermore, a SEM-EDS FEI (Inspect S50L) was required to complete the analyses. Vickers microhardness tests were performed by using test loads of $50 \mathrm{~g}, 300 \mathrm{~g}$ and $1000 \mathrm{~g}$ and a dwell time of $10 \mathrm{~s}$ using a Stiefelmayer KL2 model hardness test device.

Nanoindentation tests were conducted after a previous study of the tracks and coatings, so that those with better characteristics (low dilution, homogenization, and an acute angle between track and substrate) were selected for this assay. The nanohardness (GPa) and elastic modulus $(\mathrm{GPa})$ of the laser processed samples were measured introducing the samples in the machine Nano Indenter G200 the night before the tests in order to establish an adequate thermal equilibrium between the sample and machine. The elastic modulus of the selected bulk alloy was obtained from mechanical spectroscopy tests described in detail previously [23], using free decay elastometer equipment (Vibran Technologies AE-102) from the logarithmic decay of free oscillations of the first tone in flexural vibration mode.

\section{Results and discussion}

\subsection{Rapid solidification of bulk Ti-Fe-Nb-Sn alloys through copper mold casting}

Fig. 2 depicts the XRD patterns of the $\mathrm{Ti}_{63} \mathrm{Fe}_{23} \mathrm{Nb}_{8} \mathrm{Sn}_{6}$ and $\mathrm{Ti}_{66} \mathrm{Fe}_{20} \mathrm{Nb}_{8} \mathrm{Sn}_{6}$ alloys composed mainly of $\beta$-Ti matrix and TiFe internetallic phases (for the further alloy) and, additionally the $\mathrm{Ti}_{3} \mathrm{Sn}$ phase that appears for the further alloy. The ultrafine eutectics $\mathrm{Ti}_{63} \mathrm{Fe}_{23} \mathrm{Nb}_{8} \mathrm{Sn}_{6}$ and $\mathrm{Ti}_{66} \mathrm{Fe}_{20} \mathrm{Nb}_{8} \mathrm{Sn}_{6}$ (at\%) alloys showed very sharp and high intensity peaks, typical of eutectic ultrafine composites or even nanocrystalline metallic structures. 


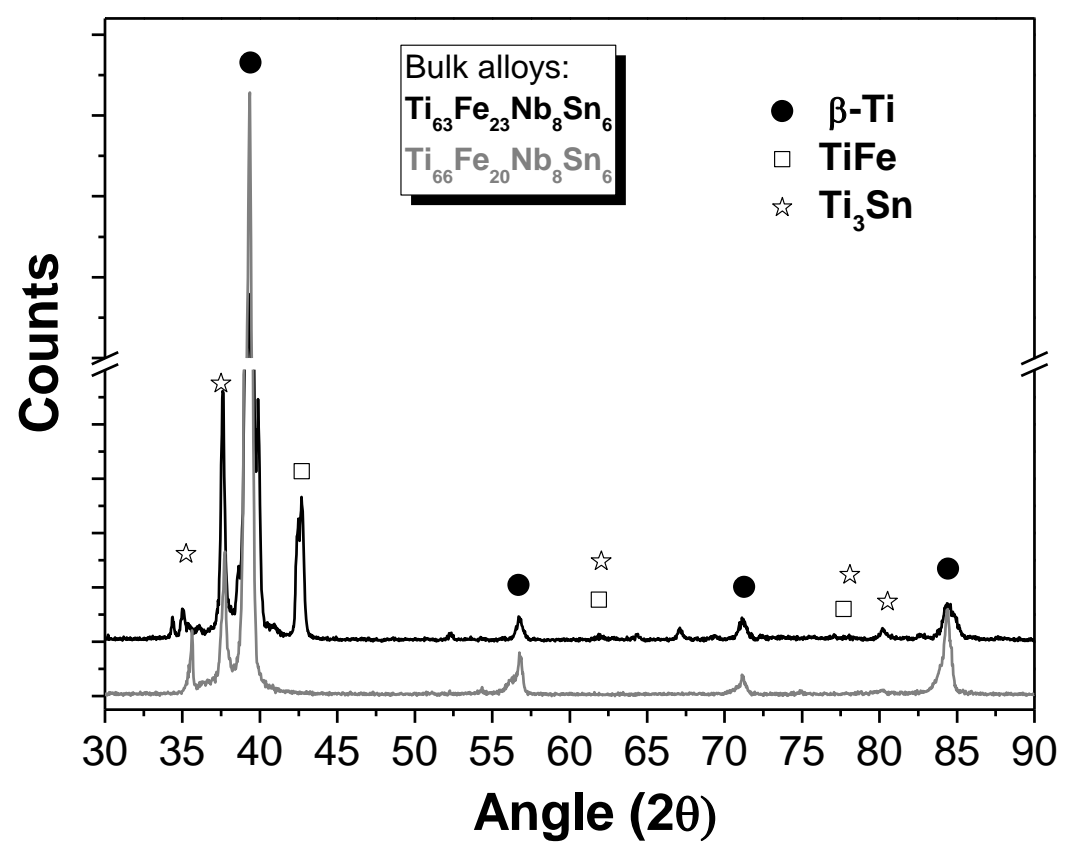

Fig. 2. XRD patterns of $\mathrm{Ti}_{63} \mathrm{Fe}_{23} \mathrm{Nb}_{8} \mathrm{Sn}_{6}$ and $\mathrm{Ti}_{66} \mathrm{Fe}_{20} \mathrm{Nb}_{8} \mathrm{Sn}_{6}$ (at\%) alloys composed mainly of the $\beta$-Ti matrix and TiFe internetallic phase $\left(\mathrm{Ti}_{63} \mathrm{Fe}_{23} \mathrm{Nb}_{8} \mathrm{Sn}_{6}\right.$ alloy) and, additionally the $\mathrm{Ti}_{3} \mathrm{Sn}$ phase that appears for the $\mathrm{Ti}_{63} \mathrm{Fe}_{23} \mathrm{Nb}_{8} \mathrm{Sn}_{6}($ at $\%)$ alloy.

Fig. 3 shows SEM microstructures (BSE) of $\mathrm{Ti}_{66} \mathrm{Fe}_{20} \mathrm{Nb}_{8} \mathrm{Sn}_{6}$ alloy for plates with thicknesses of $0.5 \mathrm{~mm}$ and $1.0 \mathrm{~mm}$. In both cases, the $\beta$-Ti phase (BCC) in the form of dendrites can be observed, which probably contains $\mathrm{Nb}$ and $\mathrm{Fe}$ in the solid solution and intermetallic particles precipitated within the interdendritic regions. The results from XRD in Fig. 2 reveal that there is a predominance of $\mathrm{Ti}_{3} \mathrm{Sn}$ intermetallic developed in such regions due to much higher peak intensities corresponding to this phase. Finer dendrites can be observed for the finer plate of $\mathrm{t}=0.5 \mathrm{~mm}$. This microstructure development is due to the higher cooling rates during solidification in smaller plate thicknesses, which happens basically due to the thicker copper-mold wall, followed by a reduction in the cooling rate as a function of increasing the plate thickness. According to the equation proposed by Lin and Johnson [24], the cooling rate in multicomponent $\mathrm{Ti}$ alloy thin plates can be calculated as follows:

$\dot{T}=\frac{k\left(T_{m}-T_{0}\right)}{C R^{2}}$ 
where $\mathrm{k}$ is the thermal conductivity, $\mathrm{T}_{\mathrm{m}}$ and $\mathrm{T}_{0}$ are the melting and room temperatures, respectively, $\mathrm{C}$ is the thermal capacity and $\mathrm{R}$ is the thickness of the plate.

Considering plates with $0.5 \mathrm{~mm}, 1.0 \mathrm{~mm}$ and $2.0 \mathrm{~mm}$ in thickness, cooling rate values of $3.9 \times 10^{4}, 9.7 \times 10^{3}$ and $2.4 \times 10^{3} \mathrm{~K} / \mathrm{s}$ have been determined based on equation (1), respectively.

Vickers hardness (HV) and elastic modulus were determined for the $\mathrm{Ti}_{66} \mathrm{Fe}_{20} \mathrm{Nb}_{8} \mathrm{Sn}_{6}$ alloy plate with $1 \mathrm{~mm}$ in thickness. An average indentation value of $417 \mathrm{HV}$ was determined (see Table 2), which can be considered low due to the presence of relatively coarse Ti-rich dendrites. However, this kind of microstructure configuration (dendrites of $\beta$-Ti enveloped by $\mathrm{Ti}_{3} \mathrm{Sn}$ intermetallics) may lead to a suitable elastic modulus of $72 \mathrm{GPa}$ measured by mechanical spectroscopy. Chaves and co-authors [23] have recently determined an elastic modulus of $65 \mathrm{GPa}$ for a rapidly quenched $\beta$-type Ti-25Nb-3Fe (wt.\%) alloy. In this case, a strong addition of $\beta$ stabilizers is pointed out as being mainly responsible for reducing the elastic modulus. Indeed, the $\mathrm{Nb}$ content is considerably high, which could increase costs associated to adopting such an alloy for implants. The combination of low $\mathrm{Nb}$-content and suitable elastic modulus found in the $\mathrm{Ti}_{66} \mathrm{Fe}_{20} \mathrm{Nb}_{8} \mathrm{Sn}_{6}$ alloy seems to be an attractive characteristic to use this alloy for biomedical purposes.

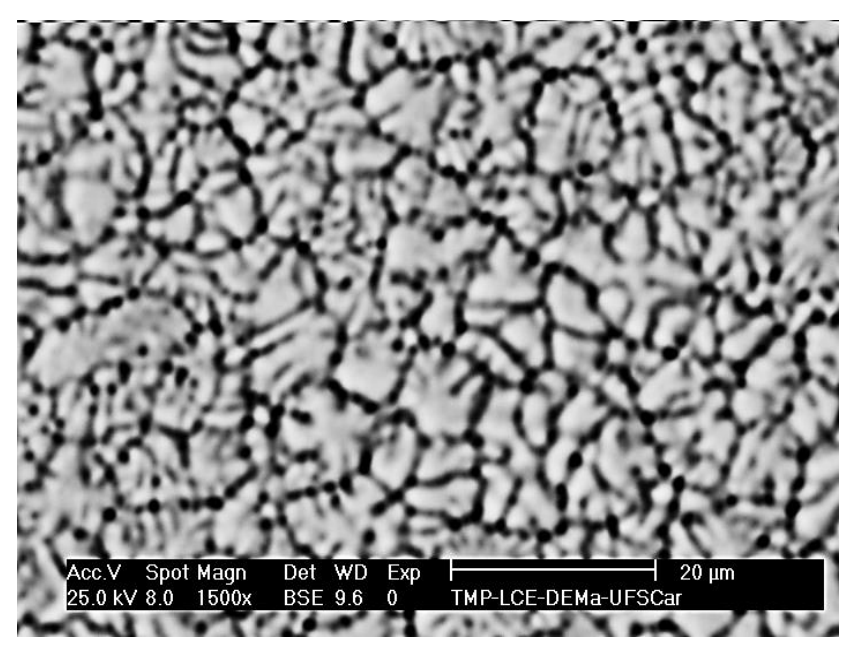

$\mathrm{t}=0.5 \mathrm{~mm}$

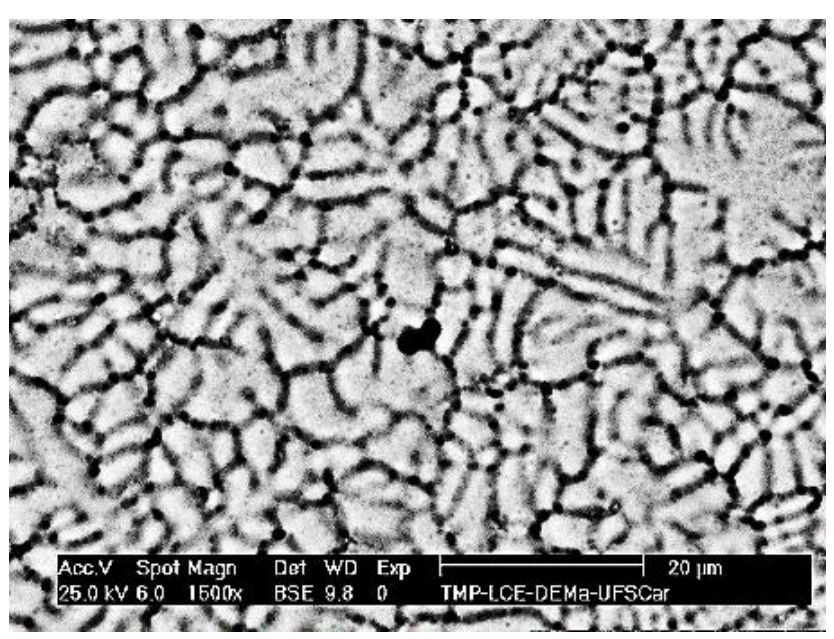

$\mathrm{t}=1.0 \mathrm{~mm}$

Fig. 3. Typical SEM images obtained for plates with different thicknesses $(t)$ along the $\mathrm{Ti}_{66} \mathrm{Fe}_{20} \mathrm{Nb}_{8} \mathrm{Sn}_{6}($ at\%) alloy casting by suction casting facility. 
Table 2. Vickers microhardness $\left(\mathrm{HV}_{0.2}\right)$ measurements for the ultrafine eutectics of $\mathrm{Ti}_{63} \mathrm{Fe}_{23} \mathrm{Nb}_{8} \mathrm{Sn}_{6}, \mathrm{Ti}_{60} \mathrm{Fe}_{23} \mathrm{Nb}_{8} \mathrm{Sn}_{9}$ and $\mathrm{Ti}_{66} \mathrm{Fe}_{20} \mathrm{Nb}_{8} \mathrm{Sn}_{6}$ (at\%) alloys.

\begin{tabular}{cc}
\hline Alloy (at.\%) & $\left(\mathrm{HV}_{1.0}\right)$ \\
\hline $\mathrm{Ti}_{63} \mathrm{Fe}_{23} \mathrm{Nb}_{8} \mathrm{Sn}_{6}$ & $488 \pm 18$ \\
\hline $\mathrm{Ti}_{60} \mathrm{Fe}_{23} \mathrm{Nb}_{8} \mathrm{Sn}_{9}$ & $608 \pm 3.0$ \\
\hline $\mathrm{Ti}_{66} \mathrm{Fe}_{20} \mathrm{Nb}_{8} \mathrm{Sn}_{6}$ & $417 \pm 15$ \\
\hline
\end{tabular}

\subsection{Features of the $\mathrm{Ti}_{66} \mathrm{Fe}_{20} \mathrm{Nb}_{8} \mathrm{Sn}_{6}$ powder alloy prepared by mechanical milling}

Fig. 4 shows the curve representing the particle size distribution of the $\mathrm{Ti}_{66} \mathrm{Fe}_{20} \mathrm{Nb}_{8} \mathrm{Sn}_{6}$ powder used to process the single tracks and coatings. It can be considered a coarse powder with a high heterogeneity of particle sizes, which means that a mixture of particles with prevalence from sizes ranging from $33 \mu \mathrm{m}$ to $230 \mu \mathrm{m}$ was found. On average, the mean particle size was $\mathrm{d}_{50}=113.4 \mu \mathrm{m}$.

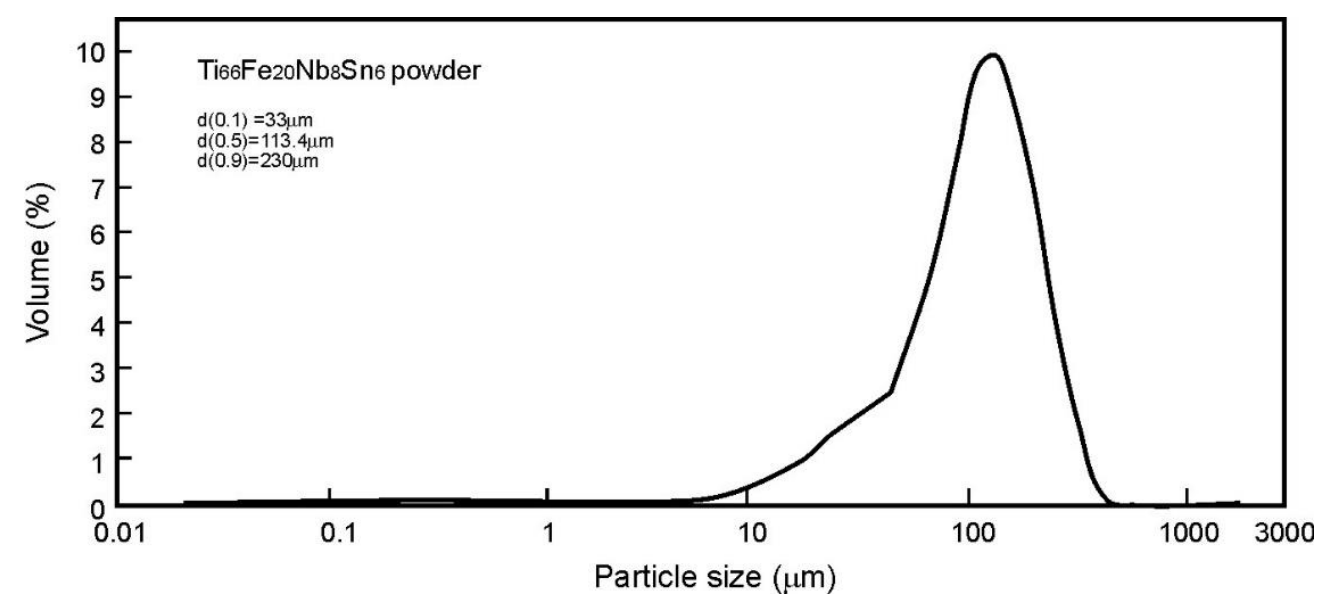

Fig. 4. Granulometric distribution of the $\mathrm{Ti}_{66} \mathrm{Fe}_{20} \mathrm{Nb}_{8} \mathrm{Sn}_{6}$ powder, processed by mechanical milling of elemental powders to be used as pre-placed material for Laser Cladding.

The resulting powder mixed through mechanical milling can be seen in Fig. 5. The large heterogeneity in particle sizes shown in the granulometric profile (Fig. 4) is confirmed by the SEM general view on the left side of Fig. 5.a. In addition, Fig. 5b depicts the presence 
of very fine fragments of $\mathrm{Nb}$ and $\mathrm{Sn}$-based powders which may be incorporated into larger particles due to the impacts and attritions involved during the mechanical milling process.

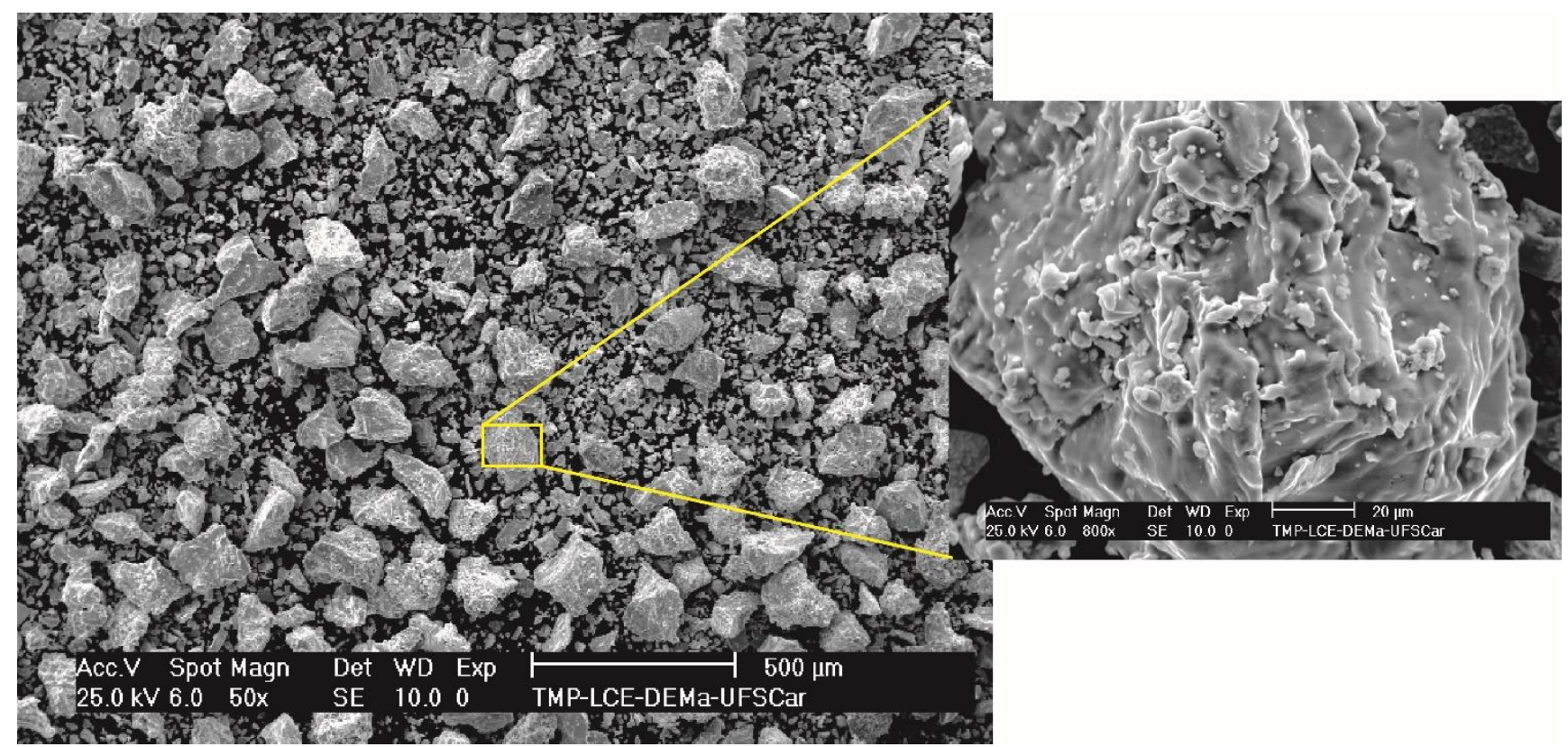

(a)

(b)

Fig. 5. (a) General and (b) detailed SEM microstructures of the pre-alloyed $\mathrm{Ti}_{66} \mathrm{Fe}_{20} \mathrm{Nb}_{8} \mathrm{Sn}_{6}$ powder used in laser process.

\subsection{Evaluation of Laser Cladding single tracks of the $\mathrm{Ti}_{66} \mathrm{Fe}_{20} \mathrm{Nb}_{8} \mathrm{Sn}_{6}$ alloy}

SEM images of selected samples in conditions tested by laser cladding were chosen to be depicted in Fig. 6 with general views of the formed molten pools in the left images (Figs. 6.a, 6.c, 6.e and 6.g) and detailed interfaces between molten and heat affected zones (HAZ) of $\mathrm{Ti}_{66} \mathrm{Fe}_{20} \mathrm{Nb}_{8} \mathrm{Sn}_{6}$ (at\%) alloy on the right side (see Figs. 6.b and 6.d). Figs. 6.b and 6.d show the presence of epitaxial growth at the interface between melted and HAZ regions with aligned dendrites growing from the substrate, according to the heat extraction direction. The microstructures that solidified right next to the bottom of the treated pool experienced an epitaxial growth and certain alignment with the growth direction, while tens of microns ahead a non-aligned growth prevailed. On the other hand, for regions farther from the interface (e.g. $\mathrm{P}=400 \mathrm{~W}$ and $\mathrm{V}_{\mathrm{b}}=66.7 \mathrm{~mm} / \mathrm{s}$ ) in Fig. 6.h, a cell-to-dendritic transition can be observed. 
During the laser cladding process, after the interruption of energy input in a specific section, melting continued, however briefly, before the onset of solidification. Thus, the cooling rates imposed and the solidification velocity at the bottom of the pool were both initially close to zero. The cooling rate started at zero and tended to be a constant value as solidification proceeded to the pool surface. The evolution of the microstructure depends on this variation of cooling rate. The presence of cells may be attributed to an increase in both the cooling rate and growth rate towards the surface of the pool. These cells are the so-called high-cooling rate cells [25-26].

Another feature to be considered is the presence of $\alpha^{\prime}$ martensite in the unmelted zone, which can be considered as a heat affected zone (HAZ). The general views of the laser tracks on the left side of Fig. 6 suggest an inhomogeneous distribution of alloying elements due to the typical short interaction times. It is often considered that at high cooling rates, due to kinetic restrictions, there is not enough time for the atoms to arrange themselves in a stable structure [27].The equation proposed by Ashby and Easterling [28] allowed for the cooling rate in laser melting traces to be estimated, based on the following expression:

$$
\dot{T}=-\frac{2 \pi k\left(T_{m}-T_{0}\right)^{2}}{A\left(\frac{q^{\prime}}{v}\right)},
$$

where $\mathrm{A}$ is the absorptivity for the laser beam, $\mathrm{v}$ is the laser scanning speed, and q' is the corrected power considering losses generated by energy absorption as latent heat when the liquid forms. q' also depends on the laser beam radius and thickness of the melted layer. In the present research, q' was considered as being the average power of each tested condition. Based on the aforementioned equation, the cooling rate values inserted in Fig. 6 could be estimated. The cooling rates related to laser processing are at least one order of magnitude higher than those calculated for the thin $\mathrm{Ti}_{66} \mathrm{Fe}_{20} \mathrm{Nb}_{8} \mathrm{Sn}_{6}$ alloy copper mold cast plates.

In SEM (BSE) analyses, heavier phases in terms of the atomic number (Z) are able to backscatter electrons more strongly than light ones, and thus appear brighter in the microstructure (chemical contrast). Nb particles and Sn-rich layers can be seen in Figs. 6.a, 
6.c, 6.e and 6.g appearing indicated by arrows as $\mathrm{Nb}$ and $\mathrm{Sn}$ are heavier elements if compared to $\mathrm{Ti}$ and $\mathrm{Fe}$. As a pure Ti substrate is used, as soon as the energy input is started in a certain region of the pre-deposited powders, a dilution process may occur. A decrease in the concentration of niobium, iron and tin must prevail in regions near the interface with higher concentration of titanium at the interface. As well as the contribution of the formed compositional gradients within the molten pool, another particular fluid flow pattern may be induced during laser treatment. This flow seems to be able to fetch $\mathrm{Sn}$ and $\mathrm{Nb}$ upwards to the regions where higher solidification velocities must predominate. This is mainly for $\mathrm{Sn}$, which shows a much lower melting temperature $\mathrm{T}_{\mathrm{m}}=232{ }^{\circ} \mathrm{C}$ when compared to the $\mathrm{Nb}$ one $\left(\mathrm{T}_{\mathrm{m}}=\right.$ $\left.2469^{\circ} \mathrm{C}\right)$. This phenomenon of transport is induced by the Marangoni convection, also called surface-tension-driven convection, consisting of the development of eddies that produce high velocities (of the order of $1 \mathrm{~m} / \mathrm{s}$ ) compared to the natural convection (of the order of $1 \mathrm{~mm} / \mathrm{s}$ ) [29]. 

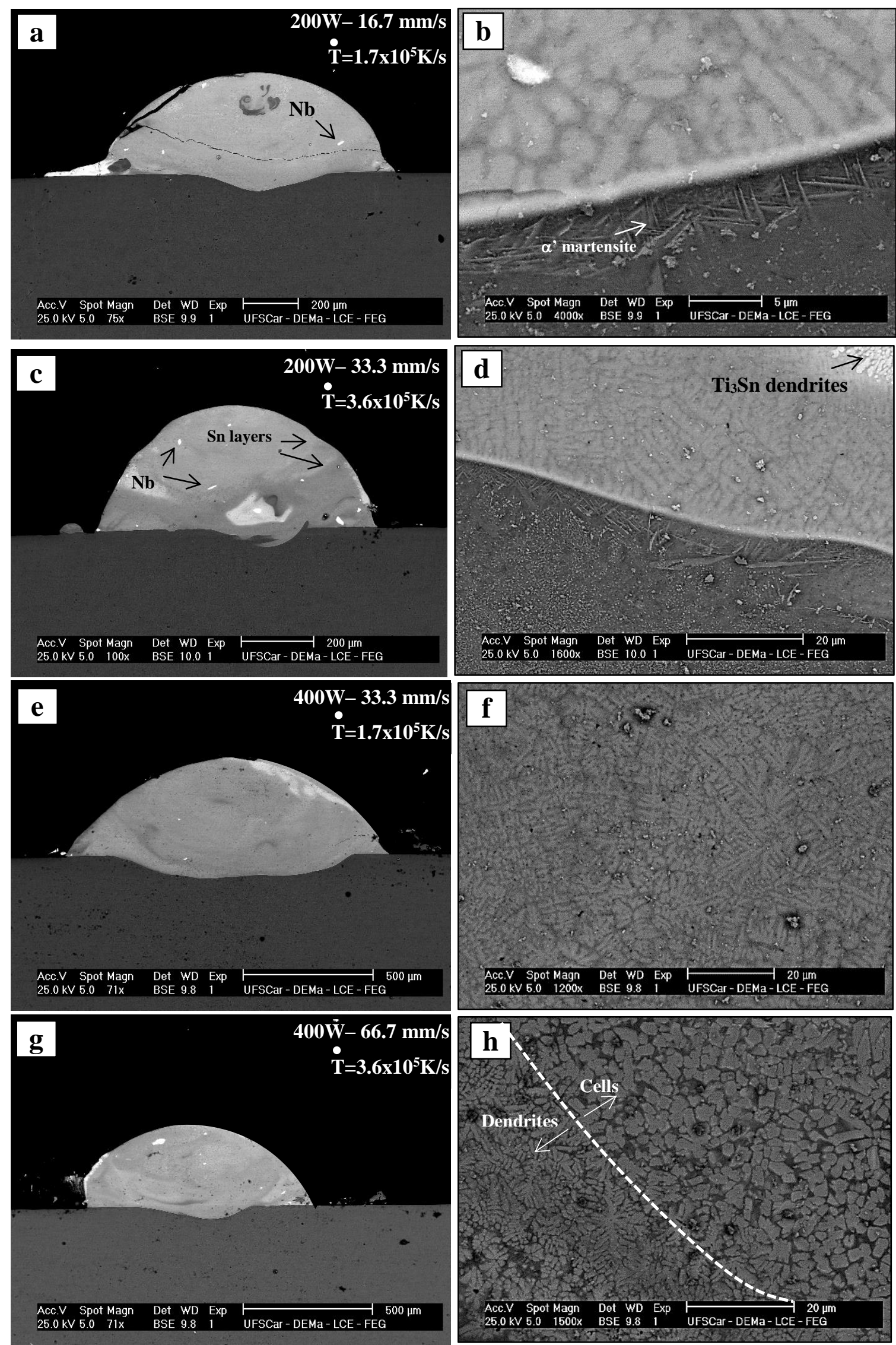

Fig. 6. Representative SEM micrographs showing: (a,c,e,g) general shape of the molten pool; (b,d) interface between single Laser affected traces of $\mathrm{Ti}_{66} \mathrm{Fe}_{20} \mathrm{Nb}_{8} \mathrm{Sn}_{6}(\mathrm{at} \%)$ alloy and the surface of the Ti substrate; and (f,h) the growth of dendrites and cells along the laser melted region. $\mathrm{P}=200 / 400 \mathrm{~W} ; \mathrm{V}_{\mathrm{b}}=16.7 / 33.3 / 66.7 \mathrm{~mm} / \mathrm{s}$. $\dot{\mathrm{T}}$ is the cooling rate. 
X-ray elemental mapping obtained by energy-dispersive spectroscopy (EDS) can reveal the compositional variations from the free surface of the pool to the substrate as can be seen in Fig. 7.

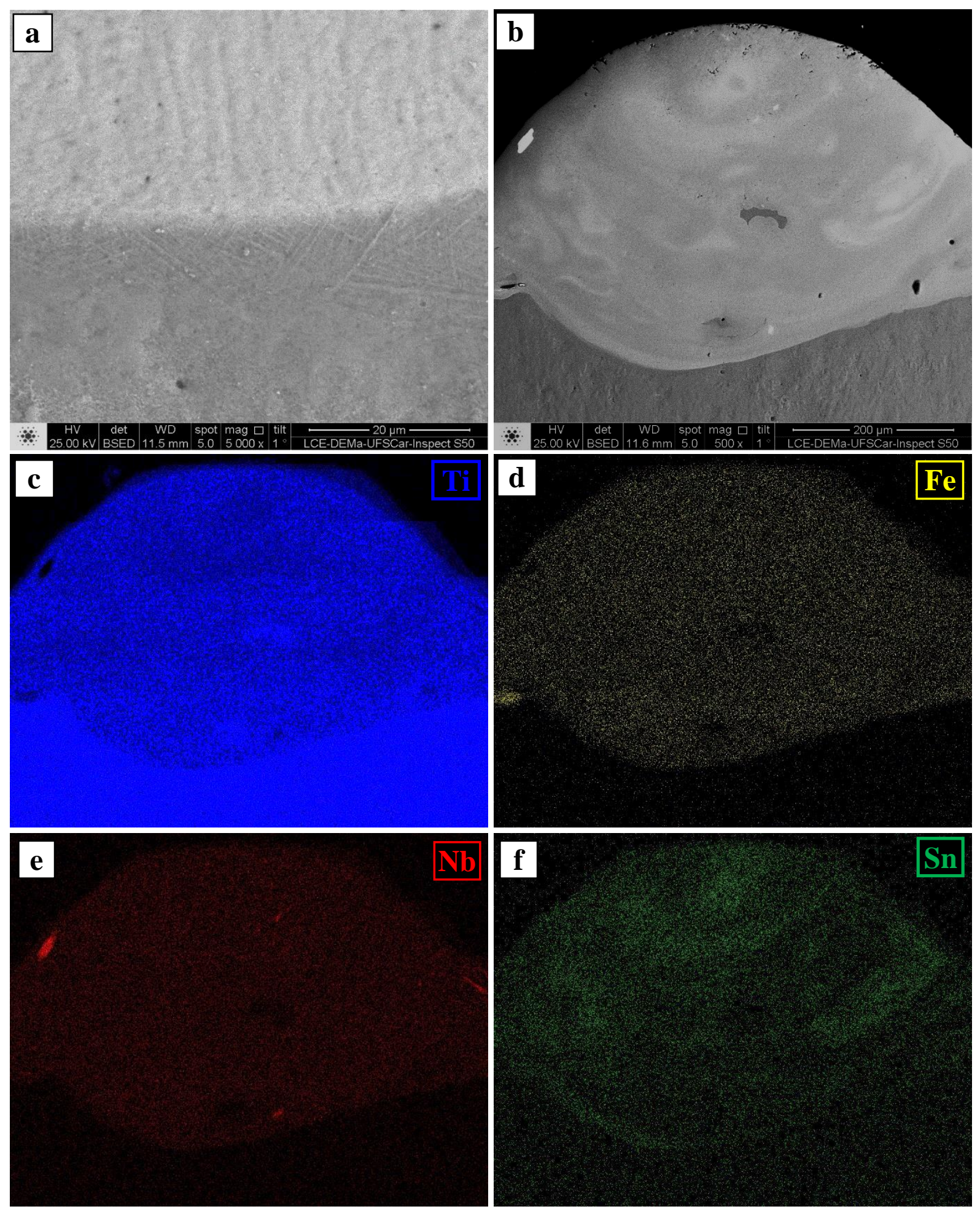

Fig. 7. (a), (b) SEM micrographs with features typically found in the interface between laser melted and heat affected zones (HAZ) of the $\mathrm{Ti}_{66} \mathrm{Fe}_{20} \mathrm{Nb}_{8} \mathrm{Sn}_{6}$ alloy, and respective X-ray elemental mapping obtained by EDS of (c) Ti-K, (d) Fe-K, (e) Nb-L and (f) Sn-L. 
The X-ray mapping by SEM-EDS shown in Fig. 7 confirms the non-uniformity of the material, depending on the laser cladding parameters adopted. Lighter areas are Sn-enriched in Fig. 7.b and correspond to green regions in Fig. 7.f. Very high cooling rates imposed during laser cladding do not provide enough time for complete melting and homogenization of the molten pool. Sn-rich regions favor the formation of $\mathrm{Ti}_{3} \mathrm{Sn}$ primary dendrites, as can be seen in Fig. 6b, shown by the black arrow. A high fraction of the $\mathrm{Ti}_{3} \mathrm{Sn}$ phase can be seen in Fig. 8, with dendritic growth near the surface of the pool and the growth of such dendrites concurs with the Sn-rich layers observed in Fig. 6 and Fig. 7.

Lee and co-authors [18] investigated ultrafine Ti-Fe-Sn eutectic by increasing the concentration of $\mathrm{Sn}$ and examining microstructure changes. The growth of micro-scale $\mathrm{Ti}_{3} \mathrm{Sn}$ dendrites uniformly embedded in the TiFe and $\beta$-Ti eutectic structure for the $\mathrm{Ti}_{68} \mathrm{Fe}_{23} \mathrm{Sn}_{9}$ alloy is stressed, whereas $\beta$-Ti primary dendrite in eutectic matrix was found for the $\mathrm{Ti}_{72} \mathrm{Fe}_{22} \mathrm{Sn}_{6}$ alloy. According to this research, the $\mathrm{Ti}_{3} \mathrm{Sn}$ dendrites may lead to slip bands that induce work hardening playing a fundamental role in plasticity during deformation. Zhang and collaborators [19] stated that the structural incompatibility between $\mathrm{Ti}_{3} \mathrm{Sn}$ and bcc FeTi and $\beta$ Ti blocks the dislocation transfer across their interfaces, which accelerates the failure around the $\mathrm{Ti}_{3} \mathrm{Sn}$ phase. 


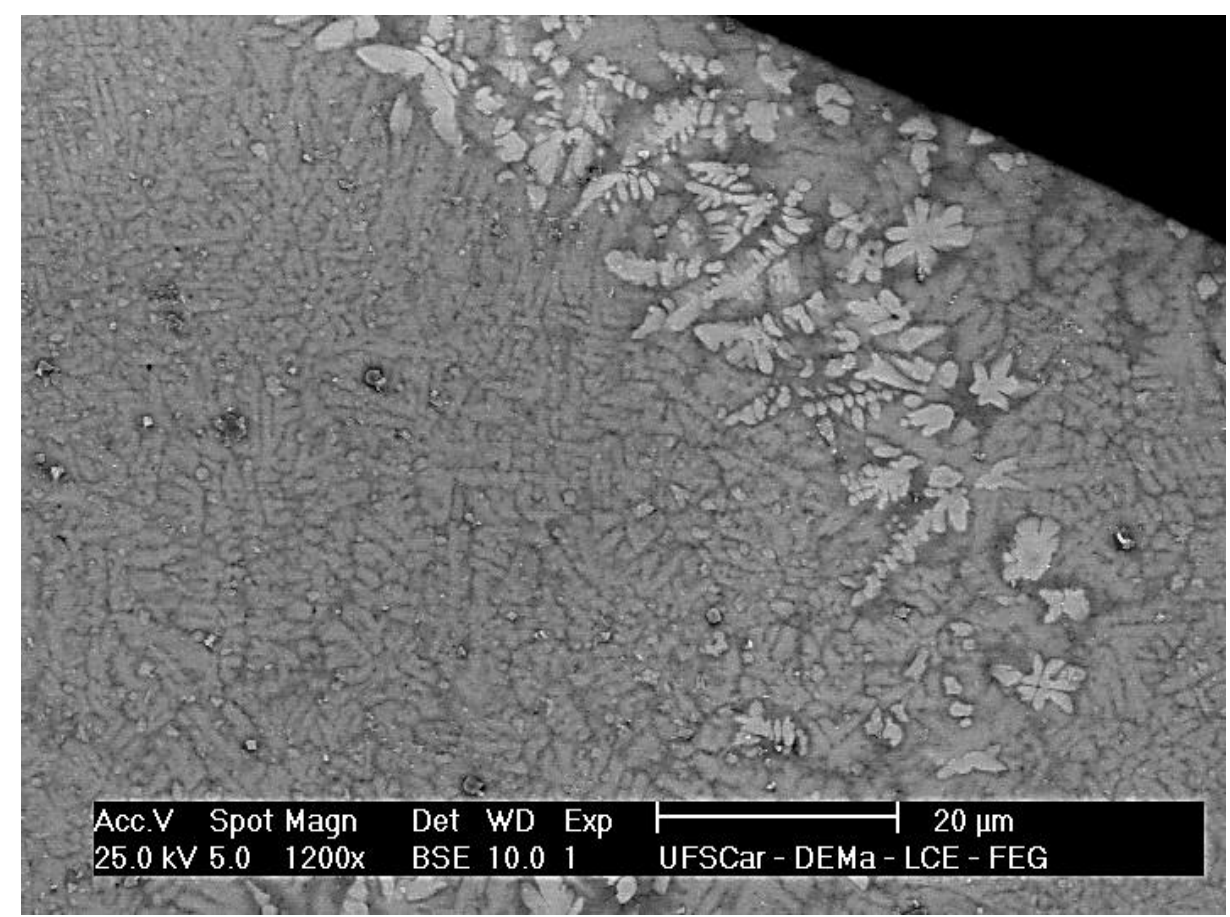

Fig. 8. SEM microstructure of the $\mathrm{Ti}_{66} \mathrm{Fe}_{20} \mathrm{Nb}_{8} \mathrm{Sn}_{6}$ alloy emphasizing the presence of fine primary $\mathrm{Ti}_{3} \mathrm{Sn}$ dendrites (brighter phases) in the molten pool obtained using the laser process with $\mathrm{P}=200 \mathrm{~W}$ and $\mathrm{V}_{\mathrm{b}}=16.7 \mathrm{~mm} / \mathrm{s}$.

If a single laser power is considered, two different experimental trends for hardness vs power density can be seen in Fig. 9. For low power densities, hardness increases with increasing laser power density (PD). As a certain PD value is achieved, a reverse behaviour starts to happen with decreasing hardness values. If lower laser powers of $200 \mathrm{~W}$ and $400 \mathrm{~W}$ are considered, it seems that for low PD values, dilution involved in the process is inhibited and, as a consequence, depletion of the elements such as $\mathrm{Nb}, \mathrm{Fe}$ and $\mathrm{Sn}$ at the unmelted/melted interface is partially avoided. As PD is increased for the processing condition associated with 400W, dilution takes place and, as a consequence, hardness diminishes. In the case of $\mathrm{P}=800 \mathrm{~W}$ and $\mathrm{P}=1000 \mathrm{~W}$, a slight reverse is noted in the hardness evolution, decreasing with increasing PD values. For power densities higher than $10 \mathrm{~J} / \mathrm{mm}^{2}$, higher laser power leads to lower hardness values. According to the cooling rate equation proposed by Ashby and Easterling (Equation (2)), an increase in laser power results in a decreasing cooling rate. Thus, lower hardness values may be explained due to the more 
diluted compositions of track and coarser microstructures formed as a consequence of relatively slower cooling conditions during laser cladding.



Fig. 9. Evolution of Vickers microhardness measured at the cross section of the Laser tracks as a function of power density (PD) for the $\mathrm{Ti}_{66} \mathrm{Fe}_{20} \mathrm{Nb}_{8} \mathrm{Sn}_{6}$ alloy.

High elastic modulus values were determined for the $\mathrm{Ti}_{66} \mathrm{Fe}_{20} \mathrm{Nb}_{8} \mathrm{Sn}_{6}$ alloy single tracks corresponding to $400 \mathrm{~W} / 33.3 \mathrm{~mm} / \mathrm{s}$ and $200 \mathrm{~W} / 16.7 \mathrm{~mm} / \mathrm{s}$. Both process conditions resulted in a modulus around $145 \mathrm{GPa}$, which is 2 times higher than that obtained for the bulk alloy. Greater values of Vickers microhardness (HV) appeared for lower laser power values and higher scanning speeds (lower PDs), such as the combination of $925 \pm 44 \mathrm{HV}$ for $400 \mathrm{~W}$, $100 \mathrm{~mm} / \mathrm{s}\left(4 \mathrm{~J} / \mathrm{mm}^{2}\right.$ in graph of Fig. 9 - triangles symbols), respectively. On the other hand, this combination of parameters might result in intense residual stress and lead to cracks across the laser track transversal section. Lower scanning speeds and higher laser power values (higher PDs) lead to greater dilutions of pre-alloyed powders (coatings with more homogenous composition), but lower contents of alloying elements, and consequently, a lower fraction of hard intermetallic phases $\left(\mathrm{TiFe}\right.$ and $\left.\mathrm{Ti}_{3} \mathrm{Sn}\right)$, resulting in lower values of microhardness measured. 


\subsection{Coatings generated by Laser Cladding of the $\mathrm{Ti}_{66} \mathrm{Fe}_{20} \mathrm{Nb}_{8} \mathrm{Sn}_{6}$ alloy}

After analysing the laser cladding tracks, the best combination of laser parameters for the production of coatings was selected based on power, $\mathrm{P}(\mathrm{W})$, laser beam scanning speed $\mathrm{V}_{\mathrm{b}}$ $(\mathrm{mm} / \mathrm{s})$, and results obtained in terms of: microhardness (HV), better composition homogeneity of clad track (better laser alloying conditions avoiding particles, or regions, enriched in one specific element: $\mathrm{Nb}, \mathrm{Fe}$ and $\mathrm{Sn}$ ) and lower dilution maintaining composition of coating similar to that of the nominal original powder composition $\mathrm{Ti}_{66} \mathrm{Fe}_{20} \mathrm{Nb}_{8} \mathrm{Sn}_{6}$.

A selected combination of laser cladding parameters was used to produce overlapped tracks. Fig. 10 shows XRD patterns of laser cladding coatings of pre-alloyed powders of $\mathrm{Ti}_{66} \mathrm{Fe}_{20} \mathrm{Nb}_{8} \mathrm{Sn}_{6}$ alloy for different combinations of laser cladding parameters: power (W) and $\mathrm{V}_{\mathrm{b}}(\mathrm{mm} / \mathrm{s})$, following the nomenclature given in Table 1 .

It can be observed from the XRD patterns that the phases formed in the coating strongly depend on the combination of laser cladding parameters. The intermetallic TiFe phase (combined with $\beta$-Ti matrix and $\mathrm{Ti}_{3} \mathrm{Sn}$ phase) was clearly formed only for lower laser power $(200 \mathrm{~W})$ and lower scanning speed $(16.7 \mathrm{~mm} / \mathrm{s})$ for the coating LC-5 (green line). In general, all the other conditions using higher laser power $(400,600$ and $800 \mathrm{~W})$ lead to the formation and identification of only $\mathrm{Ti}_{3} \mathrm{Sn}$ intermetallic and $\beta$-Ti matrix. It is likely that the laser parameters will lead to dilution conditions away from the eutectic $\beta-\mathrm{Ti}+\mathrm{TiFe}$ composition, avoiding or minimizing the formation of the intermetallic TiFe phase, in which precipitation was preferred over the copper mold cast $\mathrm{Ti}_{63} \mathrm{Fe}_{23} \mathrm{Nb}_{8} \mathrm{Sn}_{6}$ and $\mathrm{Ti}_{60} \mathrm{Fe}_{23} \mathrm{Nb}_{8} \mathrm{Sn}_{9}$ (at\%) alloys in XRD patterns in Fig. 2 and Table 2 with higher Fe additions. 


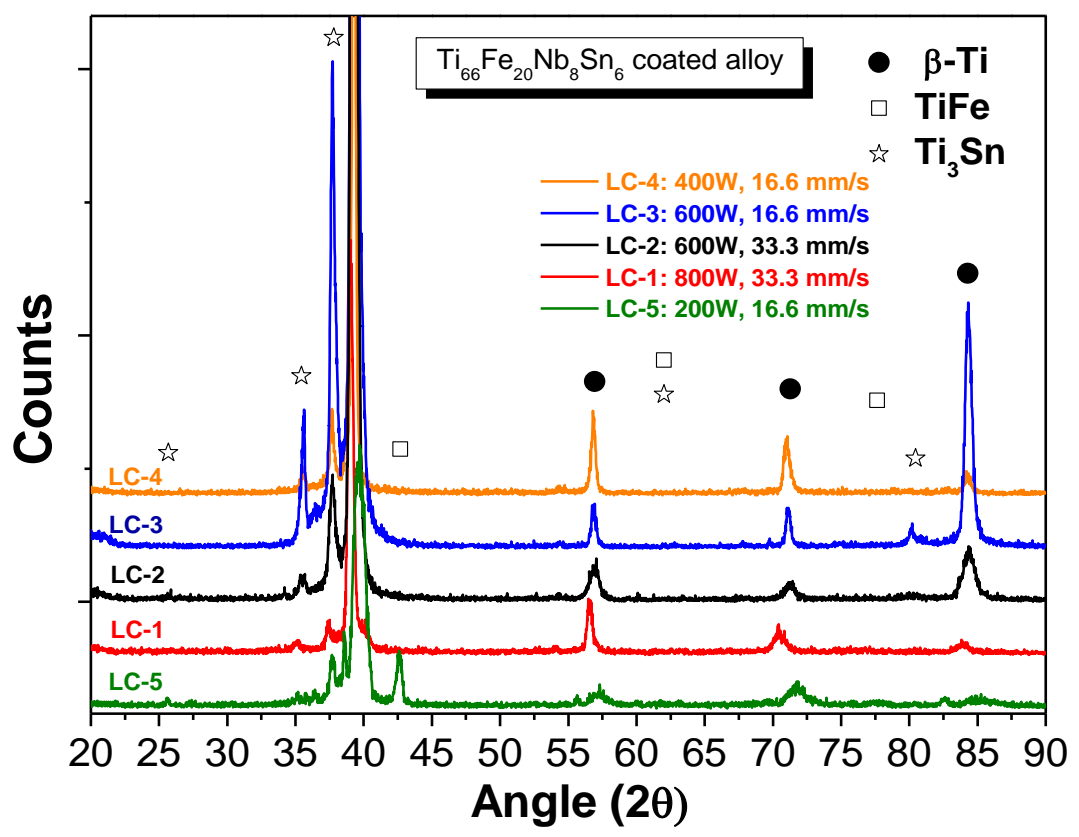

Fig. 10. XRD patterns of coatings generated from laser cladding of pre-alloyed powders of $\mathrm{Ti}_{66} \mathrm{Fe}_{20} \mathrm{Nb}_{8} \mathrm{Sn}_{6}$ alloy for different combinations of laser cladding parameters.

Fig. 11 shows SEM micrographs of typical coatings obtained by laser cladding of prealloyed powders of $\mathrm{Ti}_{66} \mathrm{Fe}_{20} \mathrm{Nb}_{8} \mathrm{Sn}_{6}$ alloy for selected combinations of laser parameters: $\mathrm{P}=$ 800W, $V_{b}=33.3 \mathrm{~mm} / \mathrm{s}\left(\right.$ Fig. 11.a) $\mathrm{P}=600 \mathrm{~W}, \mathrm{~V}_{\mathrm{b}}=16.7 \mathrm{~mm} / \mathrm{s}\left(\right.$ Fig. 11.b) $\mathrm{P}=400 \mathrm{~W}, \mathrm{~V}_{\mathrm{b}}=$ $16.7 \mathrm{~mm} / \mathrm{s}$ (Fig. 11.c); $\mathrm{P}=200 \mathrm{~W}, \mathrm{~V}_{\mathrm{b}}=16.7 \mathrm{~mm} / \mathrm{s}$ (Fig. 11.d). Although the higher laser power used in Fig. 11.a $(\mathrm{P}=800 \mathrm{~W})$ may lead to a deeper penetration of laser beam and, consequently, higher dilution, composition homogeneity of the coating resulted poor, showing flux lines with compositional variations due to chemical contrast (Z). As the laser power decreases in Figs. 11.b and 11.c ( $\mathrm{P}=600$ and $400 \mathrm{~W}$, respectively), the coating dilution diminishes leading to better composition homogeneity, and the precipitation of $\mathrm{Ti}_{3} \mathrm{Sn}$ intermetallic becomes more significant, in agreement with the XRD patterns (Fig. 10). It can be confirmed in the SEM images in BSE mode (Fig. 11.d) that the coexistence of TiFe and $\mathrm{Ti}_{3} \mathrm{Sn}$ intermetallic phases combined with $\beta$-Ti matrix only appeared for the coating LC-5 (green line in Fig. 10) with lower laser power (200 W) and a scanning speed $(16.7 \mathrm{~mm} / \mathrm{s})$. 

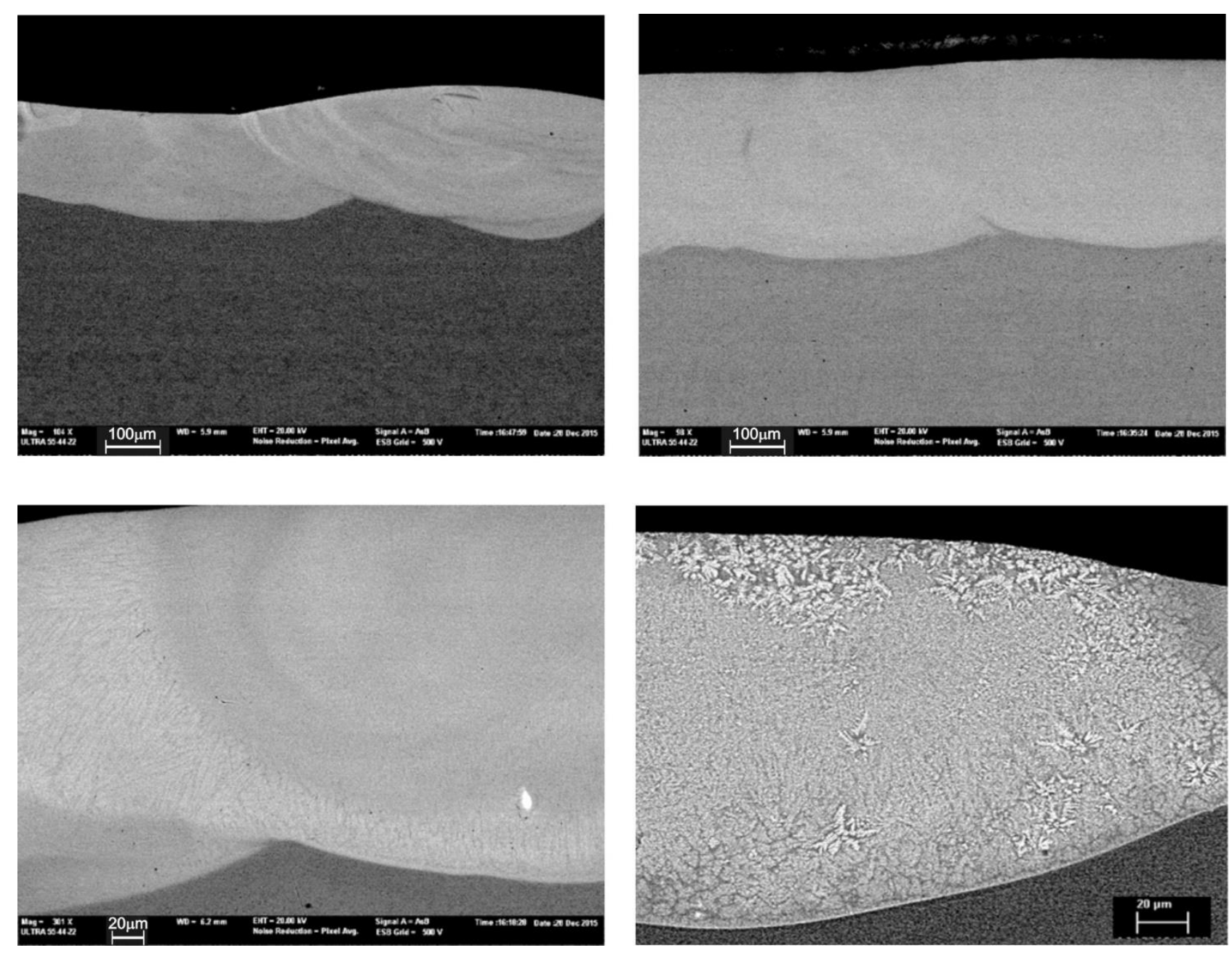

Fig. 11. SEM micrographs of typical coatings profiles obtained by laser cladding of prealloyed powders of $\mathrm{Ti}_{66} \mathrm{Fe}_{20} \mathrm{Nb}_{8} \mathrm{Sn}_{6}$ alloy for selected combinations of laser parameters: (a) 800W (33.3 mm/s) - LC-1; (b) 600W (16.7 mm/s) - LC-3; (c) 400W (16.7 mm/s) - LC-4; (d) 200W $(16.7 \mathrm{~mm} / \mathrm{s})-$ LC-5.

Fig. 12 shows EBSD patterns obtained in SEM for the laser clad coatings of $\mathrm{Ti}_{66} \mathrm{Fe}_{20} \mathrm{Nb}_{8} \mathrm{Sn}_{6}$ pre-alloyed powders using lower scanning speed $(16.7 \mathrm{~mm} / \mathrm{s})$ in the LC-5 sample with laser power of $200 \mathrm{~W}$ showing inverse pole figure (IPF-colouring) with different orientations (Fig. 12.a) and an EBSD phase map (Fig. 12.b) showing dendritic $\mathrm{Ti}_{3} \mathrm{Sn}$ (red) and a TiFe intermetallic phase (yellow) dispersed in the $\beta$-Ti matrix (blue). Combined SEM-EDS X-ray maps show the distribution of elements Fe (Fig. 12.c) and Sn (Fig. 12.d) through the coating's microstructure processed at $200 \mathrm{~W}$ and $16.7 \mathrm{~mm} / \mathrm{s}(1 \mathrm{~m} / \mathrm{min})$. 

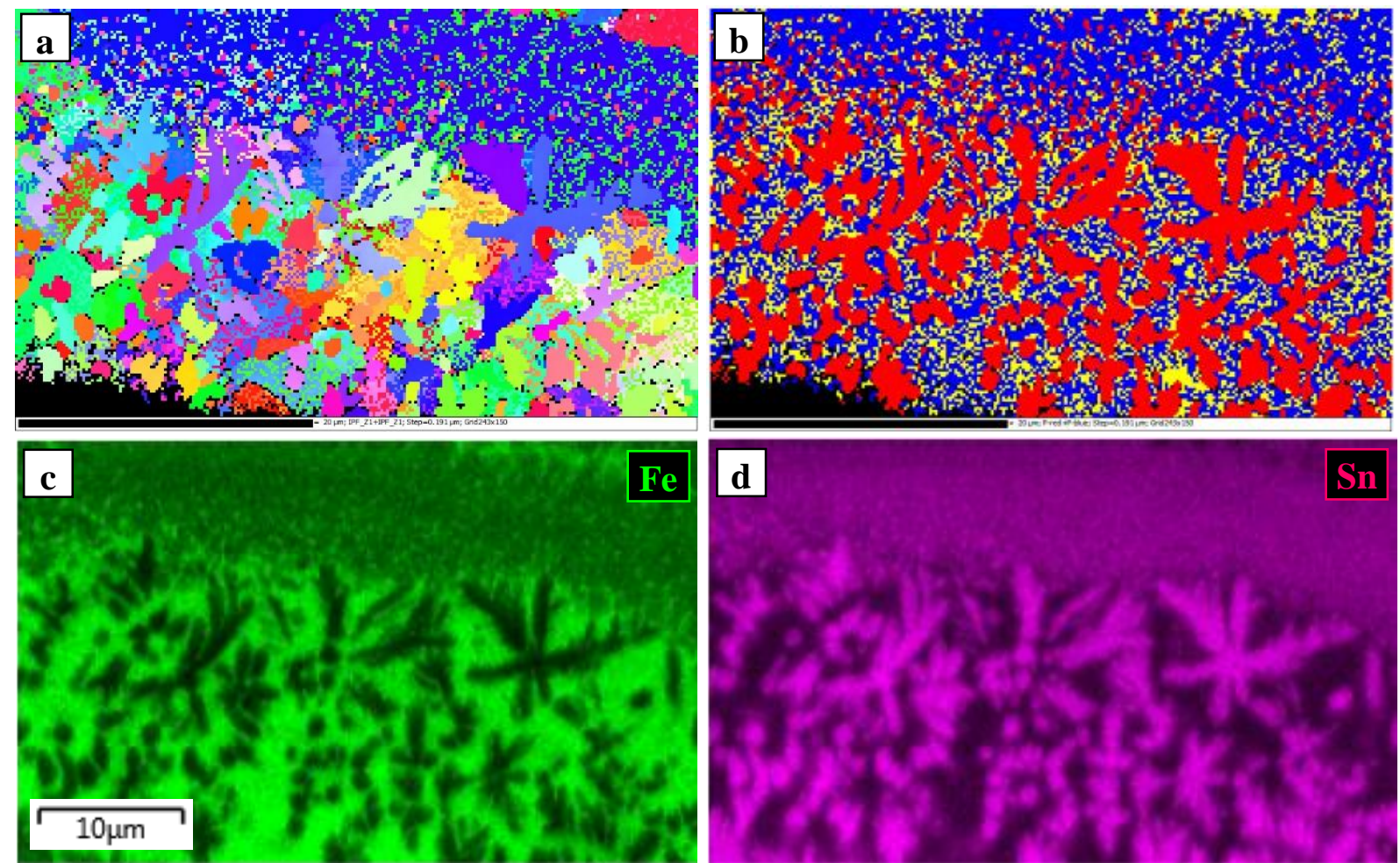

Fig. 12. SEM-EBSD results for laser clad coatings of $\mathrm{Ti}_{66} \mathrm{Fe}_{20} \mathrm{Nb}_{8} \mathrm{Sn}_{6}$ alloy (condition LC-5) based on (a) IPF-colouring with different orientations and (b) EBSD phases maps. Elemental distributions of (c) iron (Fe) and (d) tin ( $\mathrm{Sn})$ along the microstructure regarding the coated zones.

Fig. 13 shows a graph with SEM-EDS linescan semi-quantitative composition along the interface coating/ Ti substrate processed with power of $600 \mathrm{~W}$ and speed of $33.3 \mathrm{~mm} / \mathrm{s}$. It is a representative case showing that the application of high laser power to generate the T-Fe$\mathrm{Nb}-\mathrm{Sn} / \mathrm{Ti}$ coating may lead to higher dilution and composition inhomogeneity in relatively large distances from the substrate/deposit interface. The more uneven case refers to the $\mathrm{Sn}$ distribution profile in Fig. 13. 


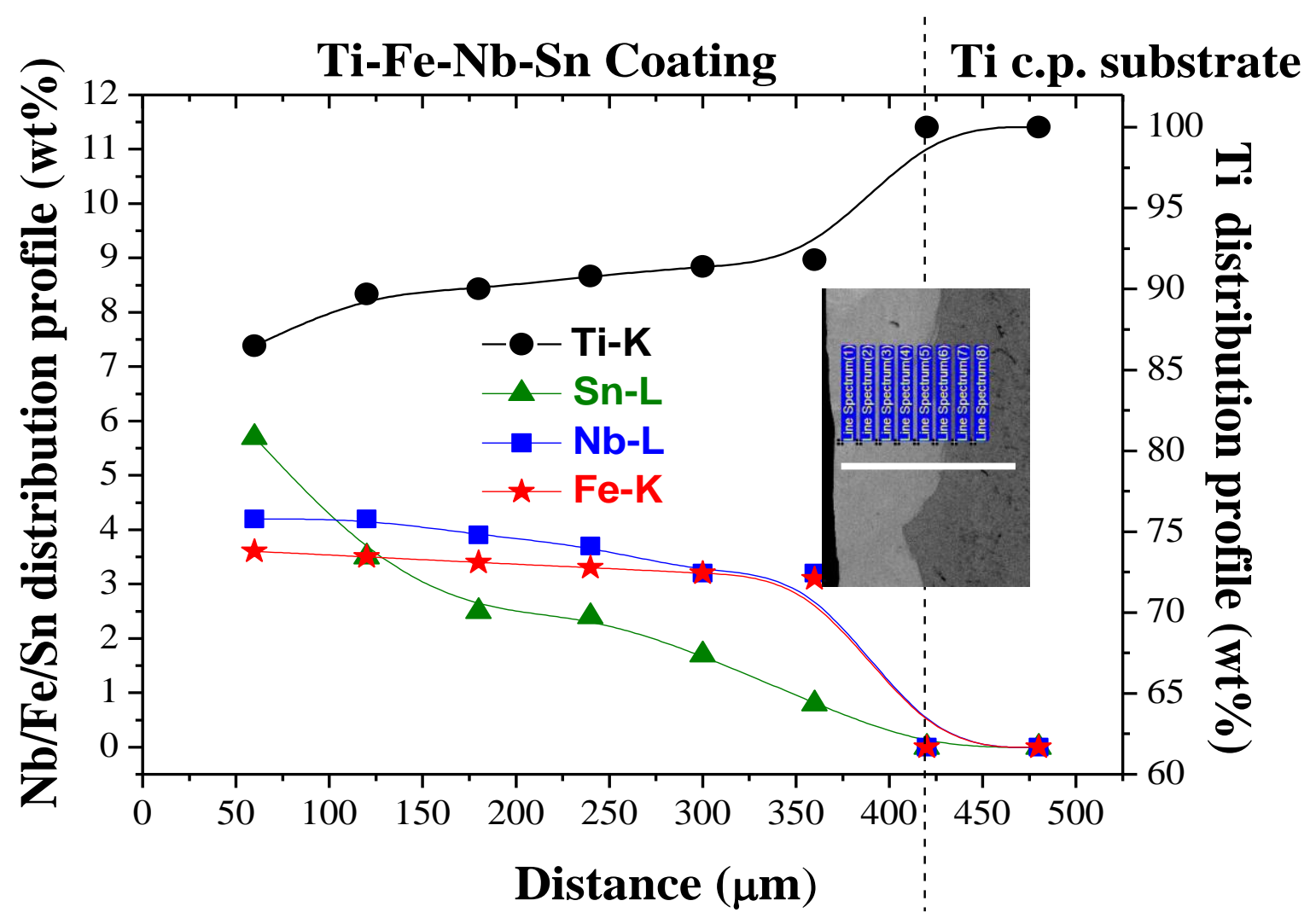

Fig. 13. Graphs showing semi-quantitative compositions through SEM-EDS linescan along the interface between the Ti-Fe-Nb-Sn coating and the Ti substrate processed with power of $600 \mathrm{~W}$ and scanning speed of $33.3 \mathrm{~mm} / \mathrm{s}$ (condition LC-2).

Table 3 shows the Vickers microhardness values for laser clad tracks and nanohardness values $(\mathrm{GPa})$ and elastic modulus $(\mathrm{GPa})$ for the respective coatings with the same combination of laser parameters, power $(\mathrm{W})$ and scanning speed $(\mathrm{mm} / \mathrm{s})$ for $\mathrm{Ti}_{66} \mathrm{Fe}_{20} \mathrm{Nb}_{8} \mathrm{Sn}_{6}$ (at\%) produced by Laser Cladding onto Ti substrate. As a reference, values of the same properties are shown for the c.p. Ti and $\mathrm{Ti}-6 \mathrm{Al}-4 \mathrm{~V}$ alloy to compare the values obtained in this work.

According to the microhardness (HV) values obtained for laser clad tracks (589- 716 $\mathrm{HV}_{0.3}$ ) depending on the laser parameters (laser power and scanning speed) imposed, it can be concluded that the hardness was very high when compared to the commercial c.p. Ti with 160 - $200 \mathrm{HV}$ and Ti-6Al-4V with $220 \mathrm{HV}$ [17]. Usually, $\beta$-Ti alloys present microhardness values between 200 and $300 \mathrm{HV}$ near the stabilization of $\beta$ phase (bcc), other Ti-based systems such as Ti-Cu alloys show microhardness values in the range of 220 to $380 \mathrm{HV}$ [13] 
and eutectic Ti-Fe presented high values of 480 to $630 \mathrm{HV}$ [14]. Even for the very hard Tibased metallic glasses (BMG), the values reached up to $710 \mathrm{HV}$ for $\left(\mathrm{Ti}_{40} \mathrm{Zr}_{10} \mathrm{Cu}_{36} \mathrm{Pd}_{14}\right)_{100-2 \mathrm{x}} \mathrm{Si}_{\mathrm{x}}$ alloys [30], comparable with the values obtained in this work of $716 \mathrm{HV}$.

Table 3. Vickers microhardness values for laser clad tracks and respective coatings with the same combination of laser parameters, power $(\mathrm{W})$ and scanning speed $(\mathrm{mm} / \mathrm{s})$ for $\mathrm{Ti}_{66} \mathrm{Fe}_{20} \mathrm{Nb}_{8} \mathrm{Sn}_{6}($ at $\%)$ and resulting values of nanohardness and elastic Modulus (GPa).

\begin{tabular}{cccccc}
\hline $\begin{array}{c}\text { Power } \\
{[\mathbf{W}]}\end{array}$ & $\begin{array}{c}\text { Scanning } \\
\text { Speed }[\mathbf{m m} / \mathbf{s}]\end{array}$ & $\begin{array}{c}\text { Vickers } \\
\text { Microhardness } \\
(\mathbf{H V} \mathbf{0 . 3})\end{array}$ & $\begin{array}{c}\text { Nanohardness } \\
(\mathbf{G P a})\end{array}$ & $\begin{array}{c}\text { Elastic } \\
\text { Modulus } \\
(\mathbf{G P a})\end{array}$ & Ref. \\
\hline $\mathbf{2 0 0}$ & 16.7 & $716 \pm 41$ & $6.5 \pm 0.4$ & $130 \pm 41$ & This work \\
\hline $\mathbf{4 0 0}$ & 33.3 & $669 \pm 19$ & $8.0 \pm 0.2$ & $148 \pm 19$ & This work \\
\hline $\mathbf{6 0 0}$ & 16.7 & $623 \pm 12$ & $4.8 \pm 0.2$ & $98 \pm 12$ & This work \\
\hline $\mathbf{8 0 0}$ & 33.3 & $645 \pm 34$ & $6.4 \pm 0.3$ & $133 \pm 34$ & This work \\
\hline $\mathbf{8 0 0}$ & 150 & $589 \pm 10$ & $7.0 \pm 0.1$ & $130 \pm 10$ & This work \\
\hline c.p. $\mathbf{T i}$ & - & $160-200$ & $2.3 \pm 0.2$ & $126 \pm 28$ & This work \\
\hline Ti-6Al-4V & - & 220 & $5.0 \pm 0.1$ & $121 \pm 3$ & {$[17]$} \\
\hline
\end{tabular}

Comparing the microhardness of clad tracks processed by laser cladding with the value obtained in a $1 \mathrm{~mm}$ thick plate of $\mathrm{Ti}_{66} \mathrm{Fe}_{20} \mathrm{Nb}_{8} \mathrm{Sn}_{6}$ alloy (417 HV) processed by copper mold casting, there was a significant hardness increase up to $72 \%$. Such an increase may be devoted to the much higher cooling rates obtained via laser cladding such as that microstructure resulted very refined with nanoscale intermetallic precipitates combined with hard $\mathrm{Ti}_{3} \mathrm{Sn}$ dendrites embedded in a $\beta$-Ti matrix. Fig. 14 shows variations of Nanohardness (GPa) and Elastic Modulus (GPa) values for coatings produced by laser cladding of $\mathrm{Ti}_{66} \mathrm{Fe}_{20} \mathrm{Nb}_{8} \mathrm{Sn}_{6}($ at $\%)$ pre-alloyed powder for different combinations of laser parameters, power, $\mathrm{P}(\mathrm{W})$ and scanning speed, $\mathrm{V}_{\mathrm{b}}(\mathrm{mm} / \mathrm{s})$.

The coatings produced by laser alloying of pre-placed $\mathrm{Ti}_{66} \mathrm{Fe}_{20} \mathrm{Nb}_{8} \mathrm{Sn}_{6}($ at $\%$ ) elemental powders lead to varied values of nanohardness $(4.8-8.0 \mathrm{GPa})$ and elastic modulus $(98-150$ GPa) depending on the laser parameters (power and scanning speed) imposed. In comparison 
to such ranges of values, the elastic modulus of the eutectic binary Ti-Fe determined from nanohardness measurements was $137 \mathrm{GPa}[9,10,13,14]$, while modulus of $\beta$-Ti alloys usually rely on the range of 55 to $80 \mathrm{GPa}[5,8-9]$.

The laser clad $\mathrm{Ti}_{66} \mathrm{Fe}_{20} \mathrm{Nb}_{8} \mathrm{Sn}_{6}$ (at\%) alloy coating led to a minimum mean value of 98 GPa (condition LC-3), which is lower than that reported for c.p. Ti and Ti-6Al-4V (126 GPa and $121 \mathrm{GPa}$, respectively) [17]. Thus, considering both microstructure characteristics and basic properties evaluation, such as hardness and elastic modulus, the laser cladding of $\mathrm{Ti}_{66} \mathrm{Fe}_{20} \mathrm{Nb}_{8} \mathrm{Sn}_{6}$ (at \%) pre-alloyed powder is able to produce ultrafine composite coatings for implants as a promising route. To the best of our knowledge, it is the first time that combined additions of $\mathrm{Sn}$ and $\mathrm{Nb}$ are performed for the eutectic Ti-Fe base alloys followed by a comprehensive characterization of the resulting laser cladding coatings into Ti substrate. As a next step, an evaluation of wear properties is desirable for the application perspective of such coatings.



Fig. 14. Variation of Nanohardness (GPa) and Elastic Modulus (GPa) values for coatings produced by laser cladding of $\mathrm{Ti}_{66} \mathrm{Fe}_{20} \mathrm{Nb}_{8} \mathrm{Sn}_{6}($ at $\%$ ) deposited over a Ti substrate for different combinations of laser parameters: power, $\mathrm{P}(\mathrm{W})$ and scanning speed, $\mathrm{V}_{\mathrm{b}}(\mathrm{mm} / \mathrm{s})$. 


\section{Conclusions}

From the results obtained in this study, the following conclusions can be drawn:

$\checkmark$ Copper mold cast $\mathrm{Ti}_{66} \mathrm{Fe}_{20} \mathrm{Nb}_{8} \mathrm{Sn}_{6}$ (at\%) bulk ultrafine nanocomposite alloy in a plate shape $(\mathrm{t}=1 \mathrm{~mm}$ thick $)$ showed a good combination of hard intermetallic $\mathrm{TiFe}$ and $\mathrm{Ti}_{3} \mathrm{Sn}$ phases finely distributed through a soft $\beta$-Ti matrix, resulting in microhardness of $417 \mathrm{HV}$ and low elastic modulus of $72 \mathrm{GPa}$ with suitable properties to be used as implant coatings.

$\checkmark$ The alloying of pre-placed $\mathrm{Ti}_{66} \mathrm{Fe}_{20} \mathrm{Nb}_{8} \mathrm{Sn}_{6}($ at $\%$ ) elemental powders. submitted to ball milling. processed through Laser Cladding over a Ti c.p. substrate successfully produced coatings with varied nanohardness $(4.8-8.0 \mathrm{GPa})$ and elastic modulus (98 - $150 \mathrm{GPa})$ depending on laser parameters (power and scanning speed) imposed.

$\checkmark$ Microstructure and properties of laser clad coatings of Ti-Nb-Fe-Sn alloy can be tuned combining laser power $(\mathrm{W})$ and scanning speeds $(\mathrm{mm} / \mathrm{s})$ resulting in varied dilution of alloying elements (coating composition) and stiffness graded coatings for implants. Rapid solidified ultrafine composites were obtained for low laser powers (200W and $400 \mathrm{~W}$ ) and scanning speeds $(16.7 \mathrm{~mm} / \mathrm{s}$ and $33.3 \mathrm{~mm} / \mathrm{s})$ and an almost fully $\beta$-Ti phase matrix for higher laser powers (600 and $800 \mathrm{~W})$ for more diluted compositions.

$\checkmark$ The addition of Sn and Fe to the Ti-Nb alloy resulted in ultrafine eutectic composite coatings which lead to high microhardness values. They are strongly related to the volume fraction of the sub-micron dendrites and the nanoscale of the eutectic lamellar spacing of hard TiFe and $\mathrm{Ti}_{3} \mathrm{Sn}$ intermetallics interacting with soft $\beta$-Ti matrix. 


\section{Acknowledgments}

The authors acknowledge the financial support provided by CNPq (National Council for Scientific and Technological Development) Universal Project \# 473777/2011-8 and FAPESP (São Paulo State Research Foundation) Thematic Project \# 2013/05987-8 and Grants \# 2015/17090-8 (BEPE of A.L.V.) and \# 2015-19978-6 (BPE of C.R.M.A.).

\section{References}

[1] G. He. J. Eckert. W. Löser. L. Schultz, Novel Ti-base nanostructure-dendrite composite with enhanced plasticity, Nat. Mater. 2 (2003) 33-37.

[2] W. Zeiger. M. Schneider. D. Scharnweber. H. Worch, Corrosion behaviour of a nanocrystalline FeA18 alloy, Nanostruct. Mater. 6 (1995) 1013-1016.

[3] W. Zhang, A. Inoue, High strength Ti-Fe-Sn ultrafine composites with large plasticity, Scripta Mater. 57 (2007) 101-104.

[4] D.K. Misra. S.W. Sohn. H. Gabrisch. W.T. Kim. D.H. Kim, High strength Ti-Fe-(In, Nb) composites with improved plasticity. Intermetallics, 18 (2010) 342-347.

[5] S.A. Souza, C. R. M. Afonso, P.L. Ferrandini, A.A. Coelho, R. Caram, Effect of cooling rate on Ti-Cu eutectoid alloy microstructure, Mater. Sci. Eng. C, 29 (2009) 1023-1028.

[6] J. Das. K.B. Kim. F. Baier. W. Löser. J. Eckert, High-strength Ti-base ultrafine eutectic with enhanced ductility, Appl. Phys. Lett. 87 (2005) 161907-1-161907-3.

[7] D. V. Louzguine-Luzgin. L. V. Louzguina-Luzgina. H. Kato. A. Inoue, Investigation of high strength metastable hypereutectic ternary $\mathrm{Ti}-\mathrm{Fe}-\mathrm{Co}$ and quaternary $\mathrm{Ti}-\mathrm{Fe}-\mathrm{Co}-(\mathrm{V}, \mathrm{Sn})$ alloys, J. Alloys Comp. 434-435 (2007) 32-35.

[8] C. R.M. Afonso, P. L. Ferrandini, A. J. R. Londono, R. Caram, High resolution transmission electron microscopy study of the hardening mechanism through phase separation in a $\beta \mathrm{Ti}-35 \mathrm{Nb}-7 \mathrm{Zr}-5 \mathrm{Ta}$ alloy for implant applications, Acta Biomater. 6 (2010) 1625-1629.

[9] F.F. Cardoso, A. Cremasco, R.J. Contieri, E.S.N. Lopes, C.R.M. Afonso, R. Caram, Hexagonal martensite decomposition and phase precipitation in $\mathrm{Ti}-\mathrm{Cu}$ alloys, Mater. Design. 32 (2011) 4608-4613. 
[10] P.N. Andrade, A.A. Coelho, C.R.M. Afonso, R.J. Contieri, MH Robert, R. Caram, Effects of Composition on Solidification Microstructure of Cast Titanium Alloys, Mater. Sci. Forum. 649 (2010) 183-188.

[11] Y.C. Kim, D.H. Bae. W.T. Kim. D.H. Kim, A development of Ti-based bulk metallic glass, Mater. Sci. Eng. A. 375-377 (2004) 127-135.

[12] C.M. Lee, W.F. Ho, C.P. Ju, J.H. Chern Lin, Structure and properties of Titanium-25 Niobium-x Iron alloys, J. Mater. Sci-Mater. Med. 13 (2002) 695-700.

[13] A. O. F. Hayama, P. N. Andrade, A. Cremasco, R. J. Contieri, C. R. M. Afonso, R. Caram, Effects of composition and heat treatment on the mechanical behavior of $\mathrm{Ti}-\mathrm{Cu}$ alloys, Mater. Design. 55 (2014) 1006-1013.

[14] R.J. Contieri, E.S.N. Lopes, M.T.L. De La Cruz, A.M. Costa, C.R.M. Afonso, R. Caram, Microstructure of Directionally Solidified Ti-Fe Eutectic Alloy with Low Interstitial and High Mechanical Strength, J. Crystal Growth. 333 (2011) 40-47.

[15] J.-J. Oak, D.V. Louzguine-Luzgin. A. Inoue, Fabrication of Ni-free Ti-based bulkmetallic glassy alloy having potential for application as biomaterial, and investigation of its mechanical properties, corrosion, and crystallization behavior, J. Mater. Res. 22 (2007) 13461353.

[16] M. A-H.Gepreel, M. Niinomi, Biocompatibility of Ti- alloys for long-term implantation. J. Mech. Behav. Biomed. Mater. 20 (2013) 407-415.

[17] A. Hynowska. E. Pellicer. J. Fornell. S. González. N. van Steenberge. S. Suriñach. A. Gebert. M. Calin. J. Eckert. M.D. Baró. J. Sort, Nanostructured $\beta$-phase Ti-31.0Fe-9.0Sn and sub- $\mu \mathrm{m}$ structured $\mathrm{Ti}-39.3 \mathrm{Nb}-13.3 \mathrm{Zr}-10.7 \mathrm{Ta}$ alloys for biomedical applications:

Microstructure benefits on the mechanical and corrosion performances, Mater. Sci. Eng. C. 32 (2012) 2418-2425

[18] C. H. Lee. J. T. Kim. S. H. Hong. G. A. Song. J. H. Jo. S. C. Moon. K. B. Kim, Investigation of the Mechanical Properties of Ti-Fe-Sn Ultrafine Eutectic Composites by Dendrite Phase Selection, Met. Mater. Int., 20 (2014) 417-421.

[19] L. Zhang, H. B. Lu, M. Calin, E. V. Pereloma, J. Eckert, High-strength ultrafine-grained Ti-Fe-Sn alloys with a bimodal structure, J. Physics: Conf. Series. 240 (2010) 1-4.

[20] D.V. Louzguine. H. Kato. L.V. Louzguina. A. Inoue, High-strength binary Ti-Fe bulk alloys with enhanced ductility, J. Mater. Res. 19 (2004) 3600-3606. 
[21] G.A. Song, J.H. Han, T.E. Kim, J.M. Park, D.H. Kim, S. Yi, Y. Seo, N.S. Lee, K.B. Kim, Heterogeneous eutectic structure in Ti-Fe-Sn alloys, Intermetallics 19 (2011) 536-540.

[22] A.C. Oliveira, R.H.M. Siqueira, R. Riva, M.S.F. Lima, One-sided laser beam welding of autogenous T-joints for 6013-T4 aluminium alloy, Mater. Des. 65 (2015) 726-736.

[23] J.M. Chaves, O. Florêncio, P.S. Silva, P.W.B. Marques, C.R.M. Afonso, Influence of phase transformations on dynamical elastic modulus and anelasticity of beta $\mathrm{Ti}-\mathrm{Nb}-\mathrm{Fe}$ alloys for biomedical applications, J. Mech. Beh. Biom. Mater. 46 (2015) 184-196.

[24] X.H. Lin. W.L. Johnson, Formation of Ti-Zr-Cu-Ni bulk metallic glasses, J. Appl. Phys.78 (1995) 6514-6519.

[25] W Kurz and JD Fisher, Fundamentals of Solidification, Switzerland: Trans Tech Public; 1992.

[26] C Brito. G Reinhart. H Nguyen-Thi. N Mangelinck-Noël. N Cheung. J.E. Spinelli, A Garcia. High cooling rate cells, dendrites, microstructural spacings and microhardness in a directionally solidified Al-Mg-Si alloy, J. Alloys Compd. 636 (2015) 145-149.

[27] C.A. Aliravci, M.O. Pekguleryuz, Calculation of phase diagrams for the meta- stable AlFe phases forming in direct-chill (DC)-cast aluminum alloy ingots, Calphad. 22 (1998) 147155.

[28] M.F. Ashby. K.E. Easterling, The transformation hardening of steel surfaces by laser beams-I: hypo-eutectoid steels, Acta Met. 32 (1984) 1935-1948.

[29] P. Gargarella, A. Almeida, R. Vilar, CRM Afonso CRM, S. Peripolli, CT Rios, C Bolfarini, WJ Botta, CS Kiminami, Formation of Fe-based glassy matrix composite coatings by laser processing, Surf Coat Tech. 240 (2014) 336-343.

[30] P. H. Tsai, K. T. Hsu, J. H. Ke, H. C. Lin, J. S. C. Jang \& J. C. Huang, Microalloying effect of Si on mechanical properties of Ti based bulk metallic glass, Materials Technology: Advanced Functional Materials 30 (2015) 162-166. 


\section{List of Figure Captions}

Fig. 1. Sequence of processing steps carried out in the Ti-Fe-Nb-Sn alloys: (a) rapid solidification by copper mold in suction casting apparatus followed by a comprehensive microstructural characterization; (b) powder preparation to allow for laser melting to be performed following two conditions, which are: single tracks and overlapped tracks (resultant coatings).

Fig. 2. XRD patterns of $\mathrm{Ti}_{63} \mathrm{Fe}_{23} \mathrm{Nb}_{8} \mathrm{Sn}_{6}$ and $\mathrm{Ti}_{66} \mathrm{Fe}_{20} \mathrm{Nb}_{8} \mathrm{Sn}_{6}$ (at\%) alloys composed mainly of $\beta$-Ti matrix and TiFe internetallic phase $\left(\mathrm{Ti}_{63} \mathrm{Fe}_{23} \mathrm{Nb}_{8} \mathrm{Sn}_{6}\right.$ alloy) and, additionally the $\mathrm{Ti}_{3} \mathrm{Sn}$ phase that appears for the $\mathrm{Ti}_{63} \mathrm{Fe}_{23} \mathrm{Nb}_{8} \mathrm{Sn}_{6}($ at $\%)$ alloy.

Fig. 3. Typical SEM images obtained for plates with different thickness ( $t$ ) along the $\mathrm{Ti}_{66} \mathrm{Fe}_{20} \mathrm{Nb}_{8} \mathrm{Sn}_{6}($ at\%) alloy casting by suction casting facility.

Fig. 4. Granulometric distribution of the $\mathrm{Ti}_{66} \mathrm{Fe}_{20} \mathrm{Nb}_{8} \mathrm{Sn}_{6}$ powder, processed by mechanical milling of elemental powders to be used as pre-placed material for Laser Cladding.

Fig. 5. (a) General and (b) detailed SEM microstructures of the pre-alloyed $\mathrm{Ti}_{66} \mathrm{Fe}_{20} \mathrm{Nb}_{8} \mathrm{Sn}_{6}$ powder used in laser process.

Fig. 6. Representative SEM micrographs showing: (a,c,e,g) general shape of the molten pool; $(\mathrm{b}, \mathrm{d})$ interface between single Laser affected traces of $\mathrm{Ti}_{66} \mathrm{Fe}_{20} \mathrm{Nb}_{8} \mathrm{Sn}_{6}(\mathrm{at} \%)$ alloy and the surface of the Ti substrate; and (f,h) the growth of dendrites and cells along the laser melted region. $\mathrm{P}=200 / 400 \mathrm{~W} ; \mathrm{V}_{\mathrm{b}}=16.7 / 33.3 / 66.7 \mathrm{~mm} / \mathrm{s}$. $\dot{\mathrm{T}}$ is the cooling rate.

Fig. 7. (a), (b) SEM micrographs with features typically found in the interface between laser melted and heat affected zones (HAZ) of the $\mathrm{Ti}_{66} \mathrm{Fe}_{20} \mathrm{Nb}_{8} \mathrm{Sn}_{6}$ alloy, and respective X-ray elemental mapping obtained by EDS of (c) Ti-K, (d) Fe-K, (e) Nb-L and (f) Sn-L.

Fig. 8. SEM microstructure of the $\mathrm{Ti}_{66} \mathrm{Fe}_{20} \mathrm{Nb}_{8} \mathrm{Sn}_{6}$ alloy emphasizing the presence of fine primary $\mathrm{Ti}_{3} \mathrm{Sn}$ dendrites (brighter phases) in the molten pool obtained using the laser process with $\mathrm{P}=200 \mathrm{~W}$ and $\mathrm{V}_{\mathrm{b}}=16.7 \mathrm{~mm} / \mathrm{s}$.

Fig. 9. Evolution of Vickers microhardness measured at the cross section of the Laser tracks as a function of power density (PD) for the $\mathrm{Ti}_{66} \mathrm{Fe}_{20} \mathrm{Nb}_{8} \mathrm{Sn}_{6}$ alloy.

Fig. 10. XRD patterns of coatings generated from laser cladding of pre-alloyed powders of $\mathrm{Ti}_{66} \mathrm{Fe}_{20} \mathrm{Nb}_{8} \mathrm{Sn}_{6}$ alloy for different combinations of laser cladding parameters.

Fig. 11. SEM micrographs of typical coatings profiles obtained by laser cladding of prealloyed powders of $\mathrm{Ti}_{66} \mathrm{Fe}_{20} \mathrm{Nb}_{8} \mathrm{Sn}_{6}$ alloy for selected combinations of laser parameters: (a) 
800W (33.3 mm/s) - LC-1; (b) 600W (16.7 mm/s) - LC-3; (c) 400W (16.7 mm/s) - LC-4; (d) 200W $(16.7 \mathrm{~mm} / \mathrm{s})-\mathrm{LC}-5$.

Fig. 12. SEM-EBSD results for laser clad coatings of $\mathrm{Ti}_{66} \mathrm{Fe}_{20} \mathrm{Nb}_{8} \mathrm{Sn}_{6}$ alloy (condition LC-5) based on (a) IPF-colouring with different orientations and (b) EBSD phase maps. Elemental distributions of (c) iron (Fe) and (d) tin ( $\mathrm{Sn})$ along the microstructure regarding the coated zones.

Fig. 13. Graphs showing semi-quantitative compositions through SEM-EDS linescan along the interface between the $\mathrm{Ti}-\mathrm{Fe}-\mathrm{Nb}-\mathrm{Sn}$ coating and the Ti substrate processed with power of $600 \mathrm{~W}$ and scanning speed of $33.3 \mathrm{~mm} / \mathrm{s}$ (condition LC-2).

Fig. 14. Variation of Nanohardness (GPa) and Elastic Modulus (GPa) values for coatings produced by laser cladding of $\mathrm{Ti}_{66} \mathrm{Fe}_{20} \mathrm{Nb}_{8} \mathrm{Sn}_{6}($ at $\%$ ) with basis into a Ti substrate for different combinations of laser parameters: power, $\mathrm{P}(\mathrm{W})$ and scanning speed, $\mathrm{V}_{\mathrm{b}}(\mathrm{mm} / \mathrm{s})$.

\section{List of Table headings}

Table 1. Studied alloys and main parameters employed during laser cladding of the Ti-Fe-NbSn alloys.

Table 2. Vickers microhardness $\left(\mathrm{HV}_{0.2}\right)$ measurements for the ultrafine eutectics of $\mathrm{Ti}_{63} \mathrm{Fe}_{23} \mathrm{Nb}_{8} \mathrm{Sn}_{6}, \mathrm{Ti}_{60} \mathrm{Fe}_{23} \mathrm{Nb}_{8} \mathrm{Sn}_{9}$ and $\mathrm{Ti}_{66} \mathrm{Fe}_{20} \mathrm{Nb}_{8} \mathrm{Sn}_{6}$ (at\%) alloys.

Table 3. Vickers microhardness values for laser clad tracks and respective coatings with the same combination of laser parameters, power $(\mathrm{W})$ and scanning speed $(\mathrm{mm} / \mathrm{s})$ for $\mathrm{Ti}_{66} \mathrm{Fe}_{20} \mathrm{Nb}_{8} \mathrm{Sn}_{6}($ at\%) and resulting values of nanohardness and elastic Modulus (GPa). 